\title{
2-Arylthienyl-substituted 1,3-benzothiazoles as new nonlinear optical chromophores
}

\author{
Susana P. G. Costa, ${ }^{\mathrm{a}}$ Rosa M. F. Batista, ${ }^{\mathrm{a}}$ Paulo Cardoso, ${ }^{\mathrm{b}}$ Michael Belsley ${ }^{\mathrm{b}}$ and Maria \\ Manuela M. Raposo ${ }^{a_{*}}$ \\ a Centro de Química, Universidade do Minho, Campus de Gualtar \\ 4710-057 Braga, Portugal \\ b Departamento de Física, Universidade do Minho, Campus de Gualtar \\ 4710-057 Braga, Portugal
}

\begin{abstract}
A series of nonlinear optical chromophores $\mathbf{6}$ containing a substituted benzothiazole ring have been synthesized and characterized. 1,3-Benzothiazoles $\mathbf{6}$ were prepared by reacting various formyl derivatives of thienyl compounds with ortho-aminobenzenethiol in fair to excellent yields. These in turn were prepared by Suzuki coupling between aryl and thienyl precursors. The electronic interactions between donor and acceptor end groups in the conjugated 1,3benzothiazoles $\mathbf{6}$ are expressed in the intense and markedly solvatochromic CT transitions. The solvatochromic behaviour of compounds $\mathbf{6}$ was determinated by linear regression analyses of absorption maxima in several solvents, whereby benzothiazole $\mathbf{6 f}$ was found to be a very appropriate indicator dye whose absorption wavenumbers $\left(\Delta v_{\max }=1590 \mathrm{~cm}^{-1}\right)$ in aliphatic and dipolar aprotic and in aromatic and chlorinated solvents excellently correlate with the $\pi^{*}$ values defined by Kamlet and Taft. Hyper-Rayleigh scattering was used to measure the first hyperpolarizabilities $\beta$ of the mentioned compounds. Thermo gravimetric analysis (TGA) was used to evaluate their thermal stability. The experimental results indicate that good nonlinearity-thermal stability is well balanced for chromophores 6 , making them good candidates for device applications.
\end{abstract}

Keywords: Aldehydes, benzothiazoles, UV/Vis spectroscopy, nonlinear optics.

\section{Introduction}

Dipolar chromophores of the form D- $\pi-\mathrm{A}$, where $\mathrm{D}(\mathrm{A})$ is an electron donor (acceptor) group and $\pi$ is a conjugated bridge possessing large molecular second-order nonlinear optical (NLO) responses and good thermal stability are currently of interest because of their applicability to 
electrooptic devices. In such molecules, the donor and acceptor substituents provide the requisite ground-state charge asymmetry, whereas the $\pi$ conjugation system provides a pathway for the redistribution conjugation of electric charges under the influence of electric fields. $^{[1]}$

Synthetic studies have demonstrated that replacing the benzene ring of a chromophore $\pi$ bridge with easily delocalizable five member heteroaromatic rings, such as thiazole and thiophene, results in enhanced molecular hyperpolarizability. Selected thiazole, imidazole, oxazole and phenyl analogues have been prepared and characterized for comparison of the nonlinear optical properties. These studies showed that the order of nonlinearities is thiazoles $>$ oxazoles $>$ imidazoles. For electrooptical poled polymer applications, the substituted thiazoles are viewed as somewhat superior by virtue of the combination of their substantial dipole moments, red shifted absorption maxima, and to some extent enhanced nonlinearities suggesting that thiazole derivatives are good candidates as NLO chromophores. ${ }^{[2]}$ Recently, computational studies have suggested that heteroaromatic rings play a subtle role in influencing the second-order NLO response properties of donor-acceptor compounds. ${ }^{[3]}$ While the aromaticity of heteroaromatic rings affects electronic transmissions between donor and acceptor substituents, the electron-excessive or electron-deficient nature of the heterocyclic ring system also plays major role in determining the overall electron-donating and -accepting ability of the substituents: electron-excessive heterocycles act as auxiliary donors and electron-deficient heterocycles act as auxiliary acceptors. ${ }^{[4]}$

Our research on new organic and organometallic materials (oligothiophenes, benzothiazoles, thienylpyrroles, thienylphthalazines, thienyl- and bithienyl- Mo complexes) includes an interest in new molecules with application in optical and electronic devices. ${ }^{[5]}$ Recently, 2heteroaryl-substituted benzothiazoles have been investigated by us and due to their solvatochromic and fluorescence properties, benzothiazole derivatives could be used on the manufacture of organic light-emitting diodes (OLEDs) or materials with good NLO properties. $^{[5 \mathrm{e}-\mathrm{h}]}$

A number of factors prompted us to synthesize and study the properties of 2-arylthienylsubstituted 1,3-benzothiazoles 6: $(i)$ our experience in the chemistry of benzothiazoles ${ }^{[5 \mathrm{e}-\mathrm{h}]}$, (ii) the scarce mention in the literature of related systems, ${ }^{[2,3,6]}$ and (iii) the high thermal stabilities of systems derived from benzothiazole, ${ }^{[6 \mathrm{c},}{ }^{6 \mathrm{~g}-\mathrm{i}]}$ a very adequate characteristic for possible technological applications of these molecules. Accordingly and as part of our continuing 
interest in developing chromophores with NLO properties, we describe here the synthesis, the UV/Vis, the solvatochromic and nonlinear optical properties of a series of heterocyclic chromophores of the benzothiazole type containing a arylthienyl moiety substituted with various groups such as alkoxy, halogen, hydroxy and $N, N$-dialkylamino.

\section{Results and discussion}

\section{Synthesis of aldehydes 5}

Formyl derivatives 5 were synthesized with several groups (fluoro, alkoxy, hydroxy, $N, N$ dialkylamino), linked to the $\pi$ conjugating bridge in order to evaluate the effect of the donating and accepting strength of these groups on the solvatochromic and nonlinear optical properties of benzothiazoles $\mathbf{6}$. The formyl-thienylaryl derivatives $\mathbf{5 a}-\mathbf{k}$ were synthesized by $\mathrm{Pd}\left(\mathrm{PPh}_{3}\right)_{4}$ catalyzed cross-coupling reaction of thienyl- or aryl boronic acids $\mathbf{3 a}-\mathbf{b}$ and $\mathbf{4 a}-\mathbf{b}$, with the bromoaryl or bromothienyl 1a-i and 2a compounds (Figure 1).

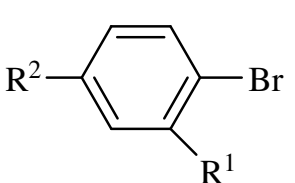

$$
\begin{aligned}
1 \text { a } & \mathrm{R}^{1}=\mathrm{H}, \mathrm{R}^{2}=\mathrm{CHO} \\
\text { b } & \mathrm{R}^{1}=\mathrm{H}, \mathrm{R}^{2}=\mathrm{OMe} \\
\text { c } & \mathrm{R}^{1}=\mathrm{R}^{2}=\mathrm{OMe} \\
\text { d } & \mathrm{R}^{1}=\mathrm{H}, \mathrm{R}^{2}=\mathrm{OH} \\
\text { e } & \mathrm{R}^{1}=\mathrm{H}, \mathrm{R}^{2}=\mathrm{NMe}_{2} \\
\text { f } & \mathrm{R}^{1}=\mathrm{H}, \mathrm{R}^{2}=\mathrm{Ph} \\
\text { g } & \mathrm{R}^{1}=\mathrm{H}, \mathrm{R}^{2}=\mathrm{PhO} \\
\text { i } & \mathrm{R}^{1}=\mathrm{H}, \mathrm{R}^{2}=\mathrm{F}
\end{aligned}
$$<smiles>[R]c1ccc(Br)s1</smiles>

3 a $\mathrm{R}^{1}=\mathrm{H}$

b $\mathrm{R}^{1}=\mathrm{CHO}$

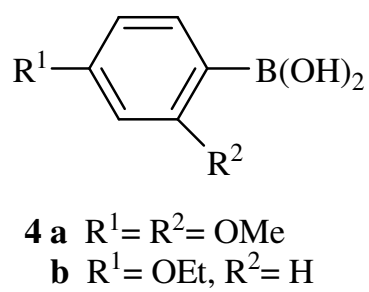

Figure 1. Structures of compounds 1, 3-4.

The bromo derivatives 1a-g, i, 1-bromonaphthalene $\mathbf{1 h}$ and 2-bromo-5-formylthiophene $\mathbf{2 a}$ were coupled under Suzuki conditions with the thienyl or aryl boronic acids $\mathbf{3 a}-\mathbf{b}$ and $\mathbf{4 a}-\mathbf{b}$ to give the formyl derivatives 5. The Suzuki coupling reactions were performed in 1,2dimethoxyethane (DME) and aqueous $2 \mathrm{M} \mathrm{Na}_{2} \mathrm{CO}_{3}$ (2 equiv.) under an argon atmosphere and $\mathrm{Pd}\left(\mathrm{PPh}_{3}\right)_{4}(6 \mathrm{~mol} \%)$ was used as palladium catalyst at $80{ }^{\circ} \mathrm{C}$ for $7-47 \mathrm{~h}$ (Scheme 1). 
<smiles>[R]c1ccc([R])s1</smiles>

$$
\begin{aligned}
& 5 \text { a } \mathrm{R}^{1}=\mathrm{H}, \mathrm{R}^{2}=4 \text {-formylphenyl } \\
& \text { b } \mathrm{R}^{1}=\text { CHO, } \mathrm{R}^{2}=4 \text {-methoxyphenyl } \\
& \text { c } \mathrm{R}^{1}=\mathrm{CHO}, \mathrm{R}^{2}=2 \text {,4-dimethoxyphenyl } \\
& \text { e } \mathrm{R}^{1}=\mathrm{CHO}, \mathrm{R}^{2}=4 \text {-hydroxyphenyl } \\
& \text { f } \mathrm{R}^{1}=\mathrm{CHO}, \mathrm{R}^{2}=4-N, N \text {-dimethylaminophenyl } \\
& \text { g } \mathrm{R}^{1}=\mathrm{CHO}, \mathrm{R}^{2}=4 \text {-biphenyl } \\
& \text { h } \mathrm{R}^{1}=\mathrm{CHO}, \mathrm{R}^{2}=4 \text {-phenoxyphenyl } \\
& \text { i } \mathrm{R}^{1}=\mathrm{CHO}, \mathrm{R}^{2}=1 \text {-naphthyl } \\
& \text { j } \mathrm{R}^{1}=\mathrm{CHO}, \mathrm{R}^{2}=4 \text {-fluorophenyl } \\
& \text { k } \mathrm{R}^{1}=\mathrm{CHO}, \mathrm{R}^{2}=4 \text {-formylphenyl }
\end{aligned}
$$

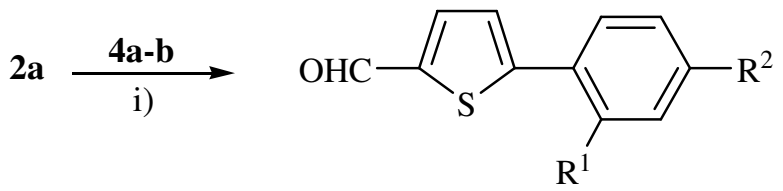

$$
\begin{aligned}
& 5 \text { c } \mathrm{R}^{1}=\mathrm{R}^{2}=\mathrm{OMe} \\
& \text { d } \mathrm{R}^{1}=\mathrm{H}, \mathrm{R}^{2}=\mathrm{OEt}
\end{aligned}
$$

Scheme 1. Synthesis of arylthienyl derivatives $\mathbf{5 a}-\mathbf{k}$ by Suzuki coupling. Reagents and conditions: i) DME, $\mathrm{Pd}\left(\mathrm{PPh}_{3}\right)_{4}(6 \mathrm{~mol} \%), \mathrm{Na}_{2} \mathrm{CO}_{3}(2 \mathrm{M}), 80{ }^{\circ} \mathrm{C}, \mathrm{Ar}$.

The formyl derivatives 5a-k where obtained in fair to good yields $15-89 \%$ (Table 1). Better yields were achieved when more activated aryl bromides were used in the Suzuki couplings. Compounds $\mathbf{5 a},{ }^{[7]} \mathbf{5 b},{ }^{[8]} \mathbf{5}{ }^{[9]}{ }^{5 \mathbf{5}},{ }^{[10]} \mathbf{5 i}^{[11]}$ and $\mathbf{5} \mathbf{j}^{[12]}$ have been previously synthesized. The synthesis of 2-(4'-formylphenyl)thiophene 5a has been reported by Otha, ${ }^{[7]}$ et al in a lower yield $(63 \%)$ through palladium catalyzed arylation of thiophene with 1-formyl-4bromobenzene. Compound $\mathbf{5 b},{ }^{[8]}$ was prepared from 2-(4'-methoxyphenyl)thiophene using a modification of Vilsmeier's formylation reaction $\left(\mathrm{POCl}_{3} / \mathrm{DMF} /\right.$ toluene $)$ in $36 \%$ yield. Compound 5c has been reported in a patent. ${ }^{[9]}$ No data about the derivative is given. Mignani, ${ }^{[10]}$ et al described the synthesis of $\mathbf{5 f}$ (91 \% yield) by lithiation of 5-(4'-N,Ndimethylaminophenyl)thiophene followed by addition of DMF in THF. No analytical data about the derivative is given. Compound 5i was described earlier by Stulin ${ }^{[11]}$ et al through Vilsmeier formylation $\left(\mathrm{POCl}_{3} / \mathrm{DMF}\right)$ of 2-(naphthalen-1-yl)thiophene. Derivative $\mathbf{5 j}$ was synthesized by Bussolari ${ }^{[12]}$ et al through a modified Suzuki cross-coupling reaction in aqueous medium in $82 \%$ yield. 
Table 1. Synthesis and UV/Vis absorption data of formyl derivatives $\mathbf{5 a}-\mathbf{k}$.

\begin{tabular}{cccccc}
\hline Bromide & $\begin{array}{c}\text { Boronic } \\
\text { acid }\end{array}$ & Aldehyde & $\begin{array}{c}\text { Yield } \\
(\boldsymbol{\%})\end{array}$ & $\begin{array}{c}\text { Reaction } \\
\text { time }[\mathbf{h}]\end{array}$ & $\begin{array}{c}\boldsymbol{\lambda}_{\max }[\mathbf{n m}]^{[\mathrm{a}]} \\
(\mathbf{l o g} \boldsymbol{\varepsilon})\end{array}$ \\
\hline $\mathbf{1 a}$ & $\mathbf{3 a}$ & $\mathbf{5 a}$ & 82 & 44 & $324(4.30)$ \\
$\mathbf{1 b}$ & $\mathbf{3 b}$ & $\mathbf{5 b}$ & 15 & 24 & $345(4.26)$ \\
$\mathbf{1 c}$ & $\mathbf{3 b}$ & & 20 & 18 & \\
$\mathbf{2 a}$ & $\mathbf{4 a}$ & $\mathbf{5 c}$ & 38 & 24 & $364(4.08)$ \\
$\mathbf{2 a}$ & $\mathbf{4 b}$ & $\mathbf{5 d}$ & 66 & 28 & $345(4.38)$ \\
$\mathbf{1 d}$ & $\mathbf{3 b}$ & $\mathbf{5 e}$ & 30 & 41 & $361(4.14)$ \\
$\mathbf{1 e}$ & $\mathbf{3 b}$ & $\mathbf{5 f}$ & 26 & 44 & $410(4.20)$ \\
$\mathbf{1 f}$ & $\mathbf{3 b}$ & $\mathbf{5 g}$ & 31 & 47 & $332(4.42)$ \\
$\mathbf{1 g}$ & $\mathbf{3 b}$ & $\mathbf{5 h}$ & 26 & 25 & $340(4.36)$ \\
$\mathbf{1 h}$ & $\mathbf{3 b}$ & $\mathbf{5 i}$ & 89 & 24 & $327(4.36)$ \\
$\mathbf{1 i}$ & $\mathbf{3 b}$ & $\mathbf{5 j}$ & 19 & 41 & $329(4.34)$ \\
$\mathbf{1 a}$ & $\mathbf{3 b}$ & $\mathbf{5 k}$ & 85 & 30 & $333(4.47)$ \\
\hline [a] Spectra were run in degassed absolute ethanol. & &
\end{tabular}

\section{Synthesis of benzothiazoles 6}

A series of benzothiazoles 6 was synthesized with either fluoro-, alkoxy- hydroxy- or $N, N$ dialkylamino- donors on the arylthienyl system. The benzothiazole moiety was obtained by reaction of $o$-aminobenzenethiol with 5-formyl-substituted derivatives 5, in DMSO at 120 ${ }^{\circ} \mathrm{C}^{[13]}$ for 30-60 min (Scheme 2). The reaction is initiated by the formation of the corresponding imine that cyclises spontaneously, yielding the benzothiazoline, which is oxidised to the benzothiazole, aided by the oxidizing character of DMSO. Purification of the crude by column chromatography gave the pure benzothiazoles 6 in fair to excellent yields $(20-91 \%)$ (Table 2). 


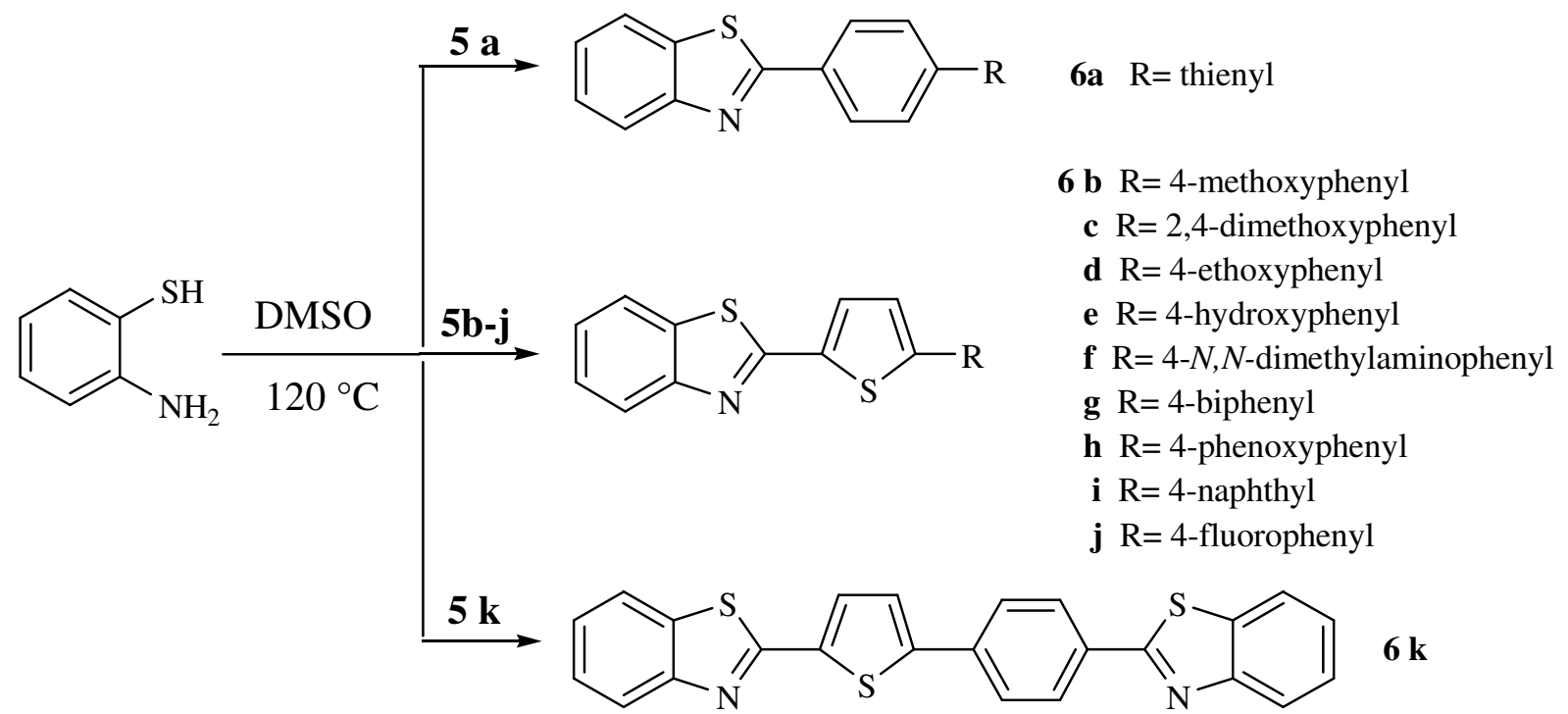

Scheme 2. Synthesis of benzothiazoles $\mathbf{6 a}-\mathbf{k}$.

Table 2. Synthesis and UV/Vis absorption data of benzothiazoles $\mathbf{6 a}-\mathbf{k}$.

\begin{tabular}{cccccc}
\hline Aldehyde & $\begin{array}{c}\text { Benzo- } \\
\text { thiazole }\end{array}$ & $\mathbf{R}$ & $\begin{array}{c}\text { Yield } \\
(\boldsymbol{\%})\end{array}$ & $\begin{array}{c}\lambda_{\max }[\mathbf{n m}]^{[\mathrm{a}]} \\
(\log \boldsymbol{\varepsilon})\end{array}$ \\
\hline $\mathbf{5 a}$ & $\mathbf{6 a}$ & thienyl & 85 & 340 & $(4.59)$ \\
$\mathbf{5 b}$ & $\mathbf{6 b}$ & $4-\mathrm{OMePh}$ & 86 & 372 & $(4.49)$ \\
$\mathbf{5 c}$ & $\mathbf{6 c}$ & $2,4-\mathrm{diOMePh}$ & 20 & 417 & $(4.26)$ \\
$\mathbf{5 d}$ & $\mathbf{6 d}$ & $4-\mathrm{OEtPh}$ & 83 & 372 & $(4.50)$ \\
$\mathbf{5 e}$ & $\mathbf{6 e}$ & $4-\mathrm{OHPh}$ & 40 & 378 & $(4.22)$ \\
$\mathbf{5 f}$ & $\mathbf{6 f}$ & $4-\mathrm{NMe}{ }_{2} \mathrm{Ph}$ & 49 & 406 & $(4.51)$ \\
$\mathbf{5 g}$ & $\mathbf{6 g}$ & $4-b i P h$ & 89 & 369 & $(4.63)$ \\
$\mathbf{5 h}$ & $\mathbf{6 h}$ & $4-\mathrm{PhOPh}$ & 91 & 365 & $(4.55)$ \\
$\mathbf{5 i}$ & $\mathbf{6 i}$ & $4-n a p h t h y l$ & 77 & 339 & $(4.50)$ \\
$\mathbf{5 j}$ & $\mathbf{6 j}$ & $4-\mathrm{FPh}$ & 90 & 355 & $(4.51)$ \\
$\mathbf{5 k}$ & $\mathbf{6 k}$ & --- & 84 & 386 & $(4.58)$
\end{tabular}

${ }^{\text {[a] }}$ Spectra were run in degassed absolute ethanol. 


\section{UV/Vis study}

The interesting photochemical and photophysical properties of compounds such as 2arylthienyl-1,3-benzothiazoles can be attributed to the presence in their molecules of different chromophores, the benzothiazole and the substituted arylthienyl systems.

Electronic absorption spectra of all benzothiazole derivatives $\mathbf{6}$ in absolute ethanol show an intense lowest energy charge-transfer absorption band in the UV/Vis region. The position of this band depends on the nature of the substitutent at position 2 of the benzothiazole molecule (Table 2, Figure 2). The reason for the substantial red shift in the investigated compounds $\mathbf{6} \mathbf{b}-$ f, $\left(\lambda_{\max }=372-406 \mathrm{~nm}\right)$ and $\mathbf{6 h}\left(\lambda_{\max }=365 \mathrm{~nm}\right)$ relative to that of unsubstituted 2-(5'-phenyl-2'thienyl)-1,3-benzothiazole ${ }^{[5 \mathrm{e}]} \quad\left(\lambda_{\max }=359 \mathrm{~nm}\right)$ and 2-(4'-(2''-thienyl)-2'-phenyl)-1,3benzothiazole $\mathbf{6 a}\left(\lambda_{\max }=340 \mathrm{~nm}\right)$ is the strong inductive and conjugative effect of the hydroxy, alkoxy or $N, N$-dialkylamino substituent in the para or in ortho/para position of the phenyl ring.

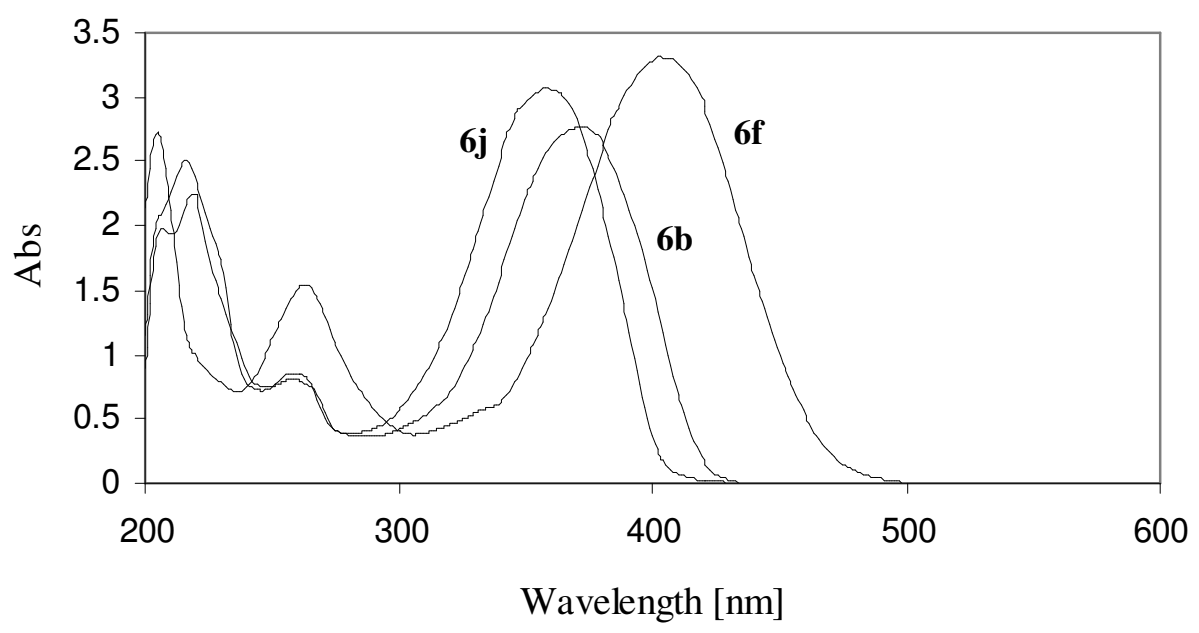

Figure 2. UV/Vis absorption spectra of compounds $\mathbf{6 b}, \mathbf{6} \mathbf{f}$ and $\mathbf{6 j}$ in ethanol.

The higher electron-donating character of $N, N$-dialkylamino ${ }^{[14]}$ groups leads to a bathochromic shift in the absorption maxima, as the longest wavelength transition is shifted from $340 \mathrm{~nm}$ for 6a to $406 \mathrm{~nm}$ for $6 \mathbf{f}$. The influence of the strength of the donor group is demonstrated by comparison of the absorption maxima of compounds $\mathbf{6 b}$ and $\mathbf{6} \mathbf{f}$ as the longest wavelength transition is shifted from $372 \mathrm{~nm}$ in 4-methoxyphenythienyl-benzothiazole $\mathbf{6 b}$ to $406 \mathrm{~nm}$ in $\mathrm{NMe}_{2} \mathrm{Phthienyl-benzothiazole} \mathbf{6 f}$. The influence of the benzothiazole moiety is demonstrated by comparison of the absorption maxima of compounds $6 \mathbf{a}$ and $6 \mathbf{k}$ as the longest wavelength 
transition is shifted from $340 \mathrm{~nm}$ in thienylphenyl-benzothiazole 6 a to $386 \mathrm{~nm}$ in 2,2'-[5' '(4"',-phenyl)thienyl]-bis-1,3-benzothiazole 6k.

The shifts of the absorption maxima are proportional to the intramolecular charge-transfer between the electron-releasing and withdrawing groups. In general, the stronger the donor and/or acceptor group, the smaller the energy difference between ground and excited states, and the longer the wavelength of absorption. ${ }^{[15]}$ According to Zyss ${ }^{[1 \mathrm{a}]}$ the increase of the $\beta$ values, characteristic of the NLO effects, is accompanied by an increase of the $\lambda_{\max }$ in the $\mathrm{UV} / \mathrm{V}$ is spectra.

\section{Solvatochromic study}

To evaluate the intermolecular forces between the solvents and the solute molecules and in order to determine the best indicator dye, we made a preliminary study of the absorption spectra of compounds 6 in 4 selected solvents of different solvatation character (diethyl ether, ethanol, chloroform and DMSO) (Table 3). We found that compound 6 f shows the longest shift in wavenumber maxima $\left(\Delta v_{\max }>1000 \mathrm{~cm}^{-1}\right)$, so a full solvatochromic study involving 14 solvents was carried out. The wavelength maxima $\lambda_{\max }$ and wavenumber maxima $v_{\max }$ of compound $\mathbf{6 f}$ are listed in Table 4 and compared with the $\pi^{*}$ values for each solvent determined by Kamlet and Taft. ${ }^{[16]}$

Table 3. Solvatochromic data $\left[\lambda_{\max }(\mathrm{nm})\right.$ and $v_{\max }\left(\mathrm{cm}^{-1}\right)$ of the charge-transfer band $]$ for chromophores 6a-k in selected solvents in comparison with $\pi^{*}$ values by Kamlet and Taft. ${ }^{[16]}$

\begin{tabular}{|c|c|c|c|c|c|c|c|c|}
\hline \multirow{3}{*}{ Compd. } & \multicolumn{8}{|c|}{ Solvent $\left(\pi^{*}\right)$} \\
\hline & \multicolumn{2}{|c|}{$\begin{array}{c}\text { Diethyl ether } \\
(0.27)\end{array}$} & \multicolumn{2}{|c|}{$\begin{array}{c}\text { Ethanol } \\
(0.54)\end{array}$} & \multicolumn{2}{|c|}{$\begin{array}{c}\text { Chloroform } \\
\text { (0.76) }\end{array}$} & \multicolumn{2}{|c|}{$\begin{array}{c}\text { DMSO } \\
(1.00)\end{array}$} \\
\hline & $\lambda_{\max }$ & $v_{\max }$ & $\lambda_{\max }$ & $v_{\max }$ & $\lambda_{\max }$ & $v_{\max }$ & $\lambda_{\max }$ & $v_{\max }$ \\
\hline $6 \mathbf{a}$ & 341.4 & 29,291 & 342.8 & 29,172 & 344.0 & 29,070 & 348.8 & 28,670 \\
\hline $6 \mathbf{b}$ & 366.4 & 27,293 & 372.0 & 26,882 & 372.4 & 26,853 & 378.0 & 26,455 \\
\hline $6 c$ & 413.6 & 24,178 & 416.6 & 24,004 & 418.4 & 23,901 & 422.8 & 23,652 \\
\hline $6 d$ & 368.0 & 27,174 & 372.0 & 26,882 & 374.0 & 26,738 & 378.6 & 26,413 \\
\hline $6 e$ & 369.5 & 27,064 & 374.0 & 26,738 & 372.8 & 26,824 & 379.0 & 26,385 \\
\hline
\end{tabular}




\begin{tabular}{rrrrrrrrr}
$\mathbf{6 f}$ & 393.8 & 25,394 & 402.6 & 24,839 & 406.0 & 24,631 & 415.2 & 24,085 \\
$\mathbf{6 g}$ & 367.6 & 27,203 & 372.0 & 26,882 & 374.5 & 26,702 & 381.0 & 26,247 \\
$\mathbf{6 h}$ & 364.6 & 27,427 & 366.5 & 27,285 & 369.8 & 27,042 & 373.8 & 26,752 \\
$\mathbf{6 i}$ & 347.4 & 28,785 & 350.6 & 28,523 & 353.4 & 28,297 & 356.8 & 28,027 \\
$\mathbf{6 j}$ & 354.2 & 28,233 & 359.0 & 27,855 & 361.5 & 27,663 & 365.8 & 27,337 \\
$\mathbf{6 k}$ & 384.4 & 26,015 & 386.5 & 25,873 & 390.0 & 25,641 & 393.0 & 25,445 \\
\hline
\end{tabular}

Table 4. Solvatochromic data $\left[\lambda_{\max }(\mathrm{nm})\right.$ and $v_{\max }\left(\mathrm{cm}^{-1}\right)$ of the charge-transfer band $]$ for chromophore $\mathbf{6} \mathbf{f}$ in 14 solvents in comparison with $\pi^{*}$ values by Kamlet and Taft. ${ }^{[16]}$

\begin{tabular}{cccc}
\hline \multirow{2}{*}{ Solvent } & $\boldsymbol{\pi}^{*}$ & \multicolumn{2}{c}{ Compound } \\
\cline { 2 - 4 } & & $\boldsymbol{\lambda}_{\max }$ & $\mathbf{v}_{\text {max }}$ \\
\hline n-hexane & -0.08 & 388.6 & 25,733 \\
diethyl ether & 0.27 & 394.8 & 25,329 \\
ethanol & 0.54 & 402.6 & 24,839 \\
toluene & 0.54 & 400.8 & 24,950 \\
1,4-dioxane & 0.55 & 402.2 & 24,863 \\
ethyl acetate & 0.55 & 401.8 & 24,888 \\
THF & 0.58 & 403.8 & 24,765 \\
methanol & 0.60 & 405.5 & 24,661 \\
acetone & 0.71 & 405.2 & 24,679 \\
acetonitrile & 0.75 & 405.6 & 24,655 \\
chloroform & 0.76 & 406.0 & 24,631 \\
DCM & 0.82 & 408.0 & 24,510 \\
DMF & 0.88 & 411.2 & 24,319 \\
DMSO & 1.00 & 414.2 & 24,143 \\
\hline
\end{tabular}

For compound $\mathbf{6 f}$ the highest energy transitions are found with $n$-hexane, a nonpolar solvent, and more polar solvents such as DMSO result in lower energy transitions, thus indicating a 
positive solvatochromic response $\left(\Delta v_{\max }=1590 \mathrm{~cm}^{-1}\right)$ that is related to a greater stabilization of the excited state relative to the ground state with increasing polarity of the solvent. Compound $\mathbf{6 f}$ shows excellent correlation between wavenumber maxima and $\pi^{*}$ values for the 14 solvents tested (Figure 3). Due to the evident solvatochromism and the good correlation with $\pi^{*}$ values $(r=0.9857)$, compound $6 \mathbf{f}$ seemed to a very appropriate solvent polarity indicator dye.

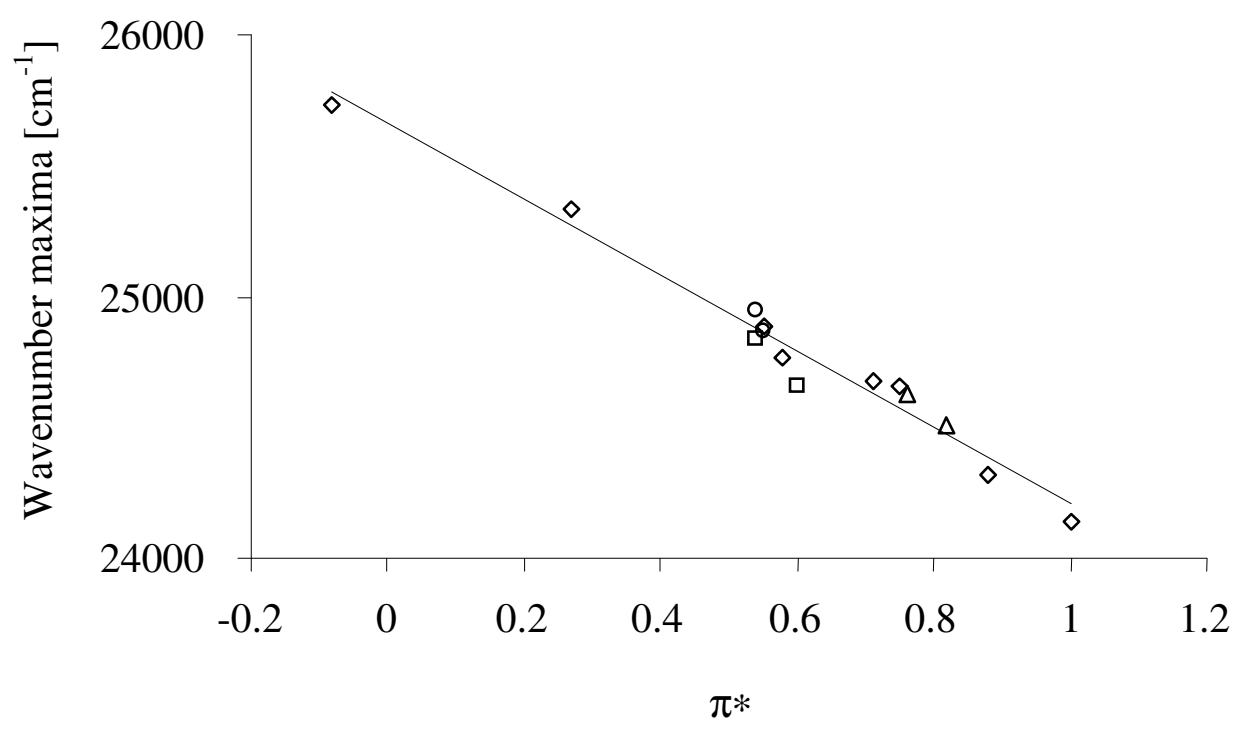

Figure 3. Correlation between absorption wavenumbers $v_{\max }$ and the $\pi^{*}$ scale according to Kamlet and Taft for compound 6f. Solvents: apolar and polar aprotic $(\diamond)$, protic ( $\square)$, chlorinated $(\Delta)$ and aromatic $(\circ)$.

\section{Nonlinear optics properties and thermal stability of benzothiazoles 6}

We have used the Hyper-Rayleigh scattering (HRS) technique ${ }^{[17]}$ to measure the first hyperpolarizability $\beta$ of the chromophores 6 using the $1064 \mathrm{~nm}$ fundamental wavelength of a laser beam. Dioxane was used as solvent, and the $\beta$ values were measured against a reference solution of $p$-nitroaniline (PNA) ${ }^{[18]}$ in the same solvent. Table 5 shows the measured values of $\beta$ together with the lowest energy absorption maximum of each compound. We have used the two-level model to calculate the static second-order hyperpolarizability $\beta_{0}{ }^{[19]}$ the results being included in Table 5. These $\beta_{0}$ values are only indicative and should, therefore, be treated with caution. 
From Table 5 it is clear that the progression of donor substituents from naphthyl-thienyl-, phenyl-thienyl, 4-fluorophenyl-thienyl, 4-methoxyphenyl-thienyl-, 2,4-dimethoxyphenylthienyl- and 4- $N, N$-dimethylaminophenyl-thienyl- results both in red shifted absorption maxima and enhanced nonlinearities as anticipated from the donor strengths of the substituents. Therefore the $\beta$ values of compounds $\mathbf{6 a}, \mathbf{6} \mathbf{i}-\mathbf{j}$ are virtually identical and 2-3 times of that of PNA, suggesting that the donating properties of these aryl-thienyl- moieties are comparable. However, derivatives 6b-e (having one or two hydroxy or methoxy- groups at ortho or ortho/para position on the aromatic ring) showed higher $\beta$ values. The $\beta$ values are 811 times that of PNA, whereas the $\beta_{0}$ values are 7-10 times that of PNA. Compound $\mathbf{6} \mathbf{f}$ having a $N, N$-dimethylamino- group at the 4-position of the aryl ring exhibits the largest $\beta$ and $\beta_{0}$ values. The $\beta$ and $\beta_{0}$ values of $6 \mathbf{f}$ are 18 and 14 times those of PNA, respectively. Comparison of the $\beta$ values for hydroxy- or alkoxy- benzothiazole derivatives $6 \mathbf{b}-\mathbf{e}$ with $N, N$ dimethylamino-substituted benzothiazole $6 \mathbf{f}$ shows that the amino donor substitution results in greatly enhanced nonlineariaties which are in agreement with the findings of Moylan ${ }^{[2 \mathrm{~b}]}$ et al. Themal stability of chromophores $\mathbf{6}$ was estimated by thermo gravimetric analysis. All samples had very high decomposition temperatures $\left(\mathrm{T}_{d}=270-450{ }^{\circ} \mathrm{C}\right)$, measured at heating rate of $20{ }^{\circ} \mathrm{C} \mathrm{min}{ }^{-1}$. Experimental results for compounds $\mathbf{6 c - d}, \mathbf{6} \mathbf{f}$ and $\mathbf{6 k}$ indicate that good nonlinearity-thermal stability is well balanced for these chromophores which possess $\beta$ values from $161 \times 10^{-30}$ to $299 \times 10^{-30}$ esu and the higher decomposition temperatures $\left(\mathrm{T}_{d}=343-450\right.$ $\left.{ }^{\circ} \mathrm{C}\right)$. Having in mind these properties and also the structure of the compounds, these chromophores will be good candidates for device applications in guest-host systems.

Table 5. UV/Vis absorptions, $\beta$ values, $\beta_{0}$ values and $\mathrm{T}_{d}$ data for benzothiazoles $\mathbf{6 a}-\mathbf{k}{ }^{[\mathrm{a}]}$

\begin{tabular}{cccccc}
\hline Compd & $\mathbf{R}$ & $\begin{array}{c}\boldsymbol{\lambda} \mathbf{m a x} \\
{[\mathbf{n m}]}\end{array}$ & $\begin{array}{c}\boldsymbol{\beta} \times \mathbf{1 0}^{-30} \\
{[\mathbf{e s u}]^{[\mathbf{b}]}}\end{array}$ & $\begin{array}{c}\boldsymbol{\beta}_{\boldsymbol{0}} \times \mathbf{1 0}^{-30} \\
{[\mathbf{e s u}]^{[\mathbf{c}]}}\end{array}$ & $\begin{array}{c}\mathbf{T}_{\boldsymbol{d}} \\
{\left[{ }^{\mathbf{0}} \mathbf{C}\right]^{[\mathbf{d}]}}\end{array}$ \\
\hline $\mathbf{6 a}$ & thienyl & 356.0 & 45 & 22 & 318 \\
$\mathbf{6 b}$ & 4-OMePh & 372.0 & 136 & 61 & 350 \\
$\mathbf{6 c}$ & $2,4-\mathrm{diOMePh}$ & 385.0 & 187 & 77 & 346 \\
$\mathbf{6 d}$ & 4-OEtPh & 374.0 & 161 & 71 & 342 \\
$\mathbf{6 e}$ & 4-OHPh & 418.0 & 169 & 55 & 270
\end{tabular}




\begin{tabular}{|c|c|c|c|c|c|}
\hline $6 f$ & $4-\mathrm{NMe}_{2} \mathrm{Ph}$ & 405.0 & 299 & 108 & 363 \\
\hline $6 \mathrm{~g}$ & 4-biPh & 376.0 & 101 & 44 & 386 \\
\hline $6 h$ & 4-OPhPh & 369.0 & 116 & 53 & 390 \\
\hline $6 \mathbf{i}$ & 4-naphthyl & 352.0 & 25 & 13 & 369 \\
\hline $\mathbf{6 j}$ & 4-FPh & 357.0 & 48 & 24 & 390 \\
\hline $6 \mathbf{k}$ & --- & 389.0 & 170 & 69 & 450 \\
\hline PNA & --- & 352.0 & $16.9^{[20]}$ & 8 & --- \\
\hline
\end{tabular}

\section{Conclusions}

Starting from the easily available formyl-arylthiophenes $\mathbf{5 a - k}$ as well as by using simple and convenient procedures, several arylthienyl-1,3-benzothiazoles 6 were obtained in fair to excellent yields by reaction of the arylthienylformyl derivatives with orthoaminobenzenenzothiol in DMSO.

The solvatochromic behaviour of benzothiazoles $\mathbf{6}$ was evaluated by linear regression analyses of absorption maxima in several solvents. Due to their pronounced solvatochromic properties benzothiazoles $\mathbf{6}$, and especially compound $\mathbf{6 f}$, are suitable to investigate the solvent polarity by means of their absorption wavenumbers.

Hyper-Rayleigh scattering was used to determine the first hyperpolarisability, $\beta$, of arylthienyl-benzothiazoles $\mathbf{6}$, the data showing that $\beta$ is dependent on the substituent(s) on the arylthienyl-moiety. It also shows that some of the compounds have high molecular nonlinearities as their values are 10-18 times higher that the well known PNA molecule. All the compounds exhibit excellent thermal stability evaluated by TGA. 
In agreement with the UV/Vis, solvatochromic and nonlinear optical studies, some of the new 2-arylthienyl-1,3-benzothiazoles 6 synthesized, could be used on the manufacture of new materials with good nonlinear optical properties.

\section{Experimental Section}

General: Thin layer chromatography was carried out on $0.25 \mathrm{~mm}$ thick precoated silica plates (Merck Fertigplatten Kieselgel $60 \mathrm{~F}_{254}$ ). Preparative chromatography was carried out on Merck Kieselgel 60 (230-400 mesh). All melting points were measured on a Gallenkamp melting point apparatus and are uncorrected. ${ }^{1} \mathrm{H}$ NMR spectra were recorded at $25{ }^{\circ} \mathrm{C}$ on a Varian 300 Unity Plus spectrometer at $300 \mathrm{MHz}$; chemical shifts are given in $\delta$ (ppm) using TMS as standard and $J$-values are given in Hz. Assignments were made by comparison of chemical shifts, peak multiplicity and $J$-values. ${ }^{13} \mathrm{C}$ NMR spectra were recorded with the same instrument at $75.4 \mathrm{MHz}$ and using the solvent peak as internal reference; peak assignments were carried out by the DEPT 135, HMQC and HMBC techniques. IR spectra were run on a FTIR Perkin-Elmer 1600 spectrophotometer. Elemental analyses were carried out on a Leco CHNS 932 instrument. Mass spectrometry analyses were performed at the C.A.C.T.I. -Unidad de Espectrometria de Masas of the University of Vigo, Spain, on a Hewlett Packard 5989 A spectrometer for low resolution spectra and a VG Autospec $\mathrm{M}$ spectrometer for high resolution mass spectra. Toluene and DME were dried by standard procedures. All Suzuki couplings were carried out under an argon atmosphere. The phenyl and thienyl bromides 1a-i and $\mathbf{2 a}$ and the phenyl and thienyl boronic acids $\mathbf{3 a}-\mathbf{b}$ and $\mathbf{4 a}-\mathbf{b}$ were purchased from Aldrich and used as received.

The experimental set-up for Hyper-Rayleigh measurements is very similar to the one presented by Clays et al. ${ }^{[17]}$ The incident beam came from a Q-switched Nd:YAG laser (10 $\mathrm{Hz}, \sim 20 \mathrm{~mJ}, \sim 10 \mathrm{~ns}$ ) at a fundamental wavelength of $1064 \mathrm{~nm}$ and was focused in the solution (beam diameter $\sim 0.5 \mathrm{~mm}$ ). The Hyper-Rayleigh signal was normalized by a second harmonic signal from a quartz plate to compensate for laser power fluctuations. The concentrations of the solutions under study were chosen so that the corresponding relative Hyper-Rayleigh signals all fell within the dynamic range of the apparatus. All solutions were previously filtered ( $0.2 \mu \mathrm{m}$ porosity) to avoid spurious signals from suspended dust and other impurities. The first hyperpolarizabilities $\beta$ of the molecules in dioxane solutions were measured using 
the external reference method. ${ }^{[18]}$ For two dilute solutions of cromophores with dominant hyperpolarizabilities along the charge transfer axis, in the same solvent, the relative hyperpolarizability is given by $\beta / \beta_{\text {ref }}=m / m$ ref where $m$ is the coefficient of variation of HRS signal with cromophore concentration. The reference chosen was a solution $1 \times 10^{-2} \mathrm{M}$ of PNA in dioxane since its $\beta$ is known to be $\beta_{\mathrm{pNA} / \mathrm{p} \text {-dioxane }}=16.9 \pm 0.410^{-30}$ esu from EFISH measurements for the same wavelength. ${ }^{[20]}$ For each solution, we estimated the linear coefficients $m$ using two experimental points: HRS signal for the solvent and HRS signal for the solution. The error associated with the HRS measured $\beta$ values is typically $10 \%$.

We were careful to test if the hyper-Rayleigh signal was artificially increased by possible molecular fluorescence near $532 \mathrm{~nm}$. To do so, we carried out measurements using two different interference filters in front of the photomultiplier, each with slightly different transmission characteristics. The transmission of both filters were centered near the second harmonic at $532 \mathrm{~nm}$, but the transmission band of the narrower filter was $1.66 \mathrm{~nm}$ (full width at half maximum), while that of the wider filter was $3.31 \mathrm{~nm}$. The transmission of each filter at the second harmonic wavelength was carefully determined using a crystalline quartz sample. Assuming that any fluorescence from the solutions was essentially constant over the transmission of both interference filters, comparing the signals obtained with the two different filters allowed one to estimate the relative strengths of the hyper-Rayleigh and possible fluorescence signals. We were unable to detect the presence of any fluorescence using this method.

Thermo gravimetric analysis of samples was carried out using TGA 50 Shimadzu instrument under high purity helium supplied at a constant $50 \mathrm{~mL} \mathrm{~min}{ }^{-1}$ flow rate. All samples were subjected to a $20^{\circ} \mathrm{C} \mathrm{min}{ }^{-1}$ heating rate and were characterized between 25 and $500{ }^{\circ} \mathrm{C}$.

\section{Experimental procedures for the synthesis of aldehydes 5 through Suzuki cross-coupling}

The bromo compounds $\mathbf{1 a}-\mathbf{i}$ or $\mathbf{2 a}(1.2 \mathrm{mmol})$ were coupled with the boronic acids $\mathbf{3 a}-\mathbf{b}$ or 4a-b $(1.6 \mathrm{mmol})$, in a mixture of $\operatorname{DME}(15 \mathrm{~mL})$ and aqueous $2 \mathrm{M} \mathrm{Na} \mathrm{CO}_{3}(1 \mathrm{~mL})$ and $\mathrm{Pd}\left(\mathrm{PPh}_{3}\right)_{4}(6 \mathrm{~mol} \%)$ at $80{ }^{\circ} \mathrm{C}$ under a argon atmosphere. The reactions where followed by TLC which determined the different reactions times (Table 1). After cooling the mixture was filtered. Ethyl acetate and a satured solution of $\mathrm{NaCl}$ were added and the phases were separated. The organic phase was washed with water $(3 \times 50 \mathrm{~mL})$ and with a solution of $\mathrm{NaOH}(10 \%)$. The organic phase obtained was dried $\left(\mathrm{MgSO}_{4}\right)$, filtered and solvent removal 
gave the crude mixture which was submitted to column chromatography affording the coupled products 5 .

2-(4'-Formylphenyl)-thiophene 5a was obtained as a yellow solid (185 mg, 82\%). Mp 69.0$69.5{ }^{\circ} \mathrm{C}\left[\right.$ lit. $\left.^{[7]} 67-68{ }^{\circ} \mathrm{C}(i-\mathrm{PrOH})\right] .{ }^{1} \mathrm{H}$ NMR $\left(\mathrm{CDCl}_{3}\right): \delta=7.15(\mathrm{~m}, 1 \mathrm{H}, 4-\mathrm{H}), 7.41(\mathrm{dd}, J=5.1$, $1.2 \mathrm{~Hz}, 1 \mathrm{H}, 5-\mathrm{H}), 7.48(\mathrm{dd}, J=3.6,1.2 \mathrm{~Hz}, 1 \mathrm{H}, 3-\mathrm{H}), 7.76-7.81$ (m, 2H, 2' and 6'-H), 7.88$7.93\left(\mathrm{~m}, 2 \mathrm{H}, 3^{\prime}\right.$ and 5'-H), 10.01 (s, $\left.1 \mathrm{H}, \mathrm{CHO}\right) \mathrm{ppm} .{ }^{13} \mathrm{C} \mathrm{NMR}\left(\mathrm{CDCl}_{3}\right): \delta=125.01,126.00$, 126.90, 128.45, 135.05, 140.06, 142.68, 191.45 ppm. IR (nujol): $v=1692(\mathrm{~s}) \mathrm{cm}^{-1} . \mathrm{C}_{11} \mathrm{H}_{8} \mathrm{OS}$ (188.25): calcd. C 70.19, H 4.25, S 17.05; found C 70.39, H 4.46, S 17.06.

2-Formyl-5-(4'-methoxyphenyl)-thiophene 5b was obtained as a beige solid (39 $\mathrm{mg}, 15 \%)$. Mp 114.4-115.8 ${ }^{\circ} \mathrm{C}$ [lit. $\left.{ }^{[8]} 119-120^{\circ} \mathrm{C}\right] .{ }^{1} \mathrm{H}$ NMR $\left(\mathrm{CDCl}_{3}\right): \delta=3.85\left(\mathrm{~s}, 3 \mathrm{H}, \mathrm{OCH}_{3}\right), 6.95(\mathrm{~d}, J$ $=9.0 \mathrm{~Hz}, 2 \mathrm{H}, 3^{\prime}$ and $\left.5^{\prime}-H\right), 7.30(\mathrm{~d}, J=3.9 \mathrm{~Hz}, 1 \mathrm{H}, 4-\mathrm{H}), 7.61\left(\mathrm{~d}, J=9.0 \mathrm{~Hz}, 2 \mathrm{H}, 2^{\prime}\right.$ and 6'$H), 7.71(\mathrm{~d}, J=3.9 \mathrm{~Hz}, 1 \mathrm{H}, 3-\mathrm{H}), 9.86(\mathrm{~s}, 1 \mathrm{H}, \mathrm{CHO}) \mathrm{ppm} .{ }^{13} \mathrm{C} \mathrm{NMR}\left(\mathrm{CDCl}_{3}\right): \delta=55.37$, $114.53,122.95,125.70,127.75,137.68,141.44,154.47,160.66,182.62 \mathrm{ppm}$. IR (nujol): $v=$ $1650(\mathrm{~s}) \mathrm{cm}^{-1} . \mathrm{C}_{12} \mathrm{H}_{10} \mathrm{O}_{2} \mathrm{~S}$ (218.28): calcd. C 66.03, H 4.58, S 14.71; found C 66.03, H 4.63, S 14.50 .

2-Formyl-5-(2',4'-dimethoxyphenyl)-thiophene 5c was obtained as a yellow solid (41 mg, 14\%). Mp 196.2-196.9 ${ }^{\circ} \mathrm{C}$ [lit. ${ }^{[9]} \mathrm{mp}$ not quoted]. ${ }^{1} \mathrm{H}$ NMR $\left(\mathrm{CDCl}_{3}\right): \delta=3.85$ (s, 3H, $\left.\mathrm{OCH}_{3}\right)$, 3.95 (s, 3H, OCH $\left.H_{3}\right), 6.52-6.62\left(\mathrm{~m}, 2 \mathrm{H}, 3^{\prime}\right.$ and 5'-H), 7.48 (d, $\left.J=3.6 \mathrm{~Hz}, 1 \mathrm{H}, 4-\mathrm{H}\right), 7.64$ (d, $J=$ $8.4 \mathrm{~Hz}, 1 \mathrm{H}, 6$ '-H), 7.70 (d, $J=3.6 \mathrm{~Hz}, 1 \mathrm{H}, 3-\mathrm{H}), 9.88$ (s, 1H, CHO) ppm. ${ }^{13} \mathrm{C} \mathrm{NMR}\left(\mathrm{CDCl}_{3}\right)$ : $\delta=55.01,55.54,98.81,105.59,115.05,124.50,129.43,136.46,141.33,150.09,157.47$, 161.71, 183.17 ppm. IR (nujol): $v=1650(\mathrm{~s}) \mathrm{cm}^{-1}$. MS (EI): $\mathrm{m} / z(\%)=248\left(\mathrm{M}^{+}, 100\right)$. $\mathrm{C}_{13} \mathrm{H}_{12} \mathrm{O}_{3} \mathrm{~S}$ (248.30): calcd. C 62.88, H 4.84, S 12.93; found C 62.99, H 5.08, S 12.79.

2-Formyl-5-(4'-ethoxyphenyl)-thiophene 5d was obtained as a yellow solid (184 $\mathrm{mg}, 66 \%)$. Mp 104.6-105.4 ${ }^{\circ} \mathrm{C} .{ }^{1} \mathrm{H}$ NMR $\left(\mathrm{CDCl}_{3}\right): \delta=1.45\left(\mathrm{t}, J=4.3 \mathrm{~Hz}, 3 \mathrm{H}, \mathrm{OCH}_{2} \mathrm{CH}_{3}\right), 4.00-4.20(\mathrm{~m}$, $\left.2 \mathrm{H}, \mathrm{OCH}_{2} \mathrm{CH}_{3}\right), 6.92-6.98\left(\mathrm{~m}, 2 \mathrm{H}, 3^{\prime}\right.$ and $\left.5^{\prime}-\mathrm{H}\right), 7.31(\mathrm{~d}, J=3.9 \mathrm{~Hz}, 1 \mathrm{H}, 4-\mathrm{H}), 7.58-7.64(\mathrm{~m}$, $2 \mathrm{H}, 2^{\prime}$ and 6'-H), $7.23(\mathrm{~d}, J=3.9 \mathrm{~Hz}, 1 \mathrm{H}, 3-\mathrm{H}), 9.87$ (s, $\left.1 \mathrm{H}, \mathrm{CHO}\right) \mathrm{ppm} .{ }^{13} \mathrm{C} \mathrm{NMR}^{-}\left(\mathrm{CDCl}_{3}\right): \delta$ $=14.71,63.63,115.00,122.88,125.51,127.76,137.78,141.34,154.63,160.06,182.69$ ppm. 
IR (nujol): $v=1650(\mathrm{~s}) \mathrm{cm}^{-1} \cdot \mathrm{C}_{13} \mathrm{H}_{12} \mathrm{O}_{2} \mathrm{~S}$ (232.30): calcd. C 67.22, H 5.17, S 13.82; found $\mathrm{C}$ 67.41, H 5.33, S 13.83 .

2-Formyl-5-(4'-hidroxyphenyl)-thiophene 5e was obtained as a pale yellow solid (73 mg, 30\%). Mp 205.6-206.2 ${ }^{\circ} \mathrm{C} .{ }^{1} \mathrm{H}$ NMR (acetone-d $\mathrm{d}_{6}$ ): $\delta=7.37-7.41$ (m, 2H, 3' and 5'-H), 7.55 $(\mathrm{d}, J=3.9 \mathrm{~Hz}, 1 \mathrm{H}, 4-\mathrm{H}), 7.53-7.54\left(\mathrm{~m}, 2 \mathrm{H}, 2^{\prime}\right.$ and 6'-H), $7.96(\mathrm{~d}, J=3.9 \mathrm{~Hz}, 1 \mathrm{H}, 3-\mathrm{H}), 9.01$ (br s, 1H, OH), 9.94 (s, 1H, CHO) ppm. ${ }^{13} \mathrm{C}$ NMR (acetone-d 6 ): $\delta=116.94,123.89,125.47$, 128.69, 139.29, 142.27, 154.81, 159.77, 183.51 ppm. IR (nujol): $v=1624$ (s) cm $\mathrm{cm}^{-1}$. MS (EI): $m / z(\%)=204\left(\mathrm{M}^{+}, 100\right)$. EI-HRMS: calcd. for $\mathrm{C}_{11} \mathrm{H}_{8} \mathrm{O}_{2} \mathrm{~S} 204.0245$, found 204.0245.

2-Formyl-5-(4'- $N, N$-dimethylaminophenyl)-thiophene 5 f was obtained as a yellow solid (72 mg, 26\%). Mp 188.9-190.1 ${ }^{\circ} \mathrm{C}$ [lit. ${ }^{[10]} \mathrm{mp}$ not quoted]. ${ }^{1} \mathrm{H}$ NMR $\left(\mathrm{CDCl}_{3}\right): \delta=3.03(\mathrm{~s}, 6 \mathrm{H}$, $\left.\mathrm{N}\left(\mathrm{CH}_{3}\right)_{2}\right), 6.72\left(\mathrm{~d}, J=8.7 \mathrm{~Hz}, 2 \mathrm{H}, 3^{\prime}\right.$ and $\left.5^{\prime}-\mathrm{H}\right), 7.24(\mathrm{~d}, J=4.2 \mathrm{~Hz}, 1 \mathrm{H}, 4-\mathrm{H}), 7.56(\mathrm{~d}, J=8.7$ $\mathrm{Hz}, 2 \mathrm{H}, 2^{\prime}$ and 6'-H), $7.68(\mathrm{~d}, J=4.2 \mathrm{~Hz}, 1 \mathrm{H}, 3-\mathrm{H}), 9.82(\mathrm{~s}, 1 \mathrm{H}, \mathrm{CHO}) \mathrm{ppm} .{ }^{13} \mathrm{C} \mathrm{NMR}$ $\left(\mathrm{CDCl}_{3}\right): \delta=29.67,40.25,112.20,121.51,12147,138.06,140.09,151.03,155.97,182.43$ ppm. IR (nujol): $v=1644$ (s) $\mathrm{cm}^{-1}$. MS (EI): $\mathrm{m} / z(\%)=231\left(\mathrm{M}^{+}, 100\right)$. EI-HRMS: calcd. for $\mathrm{C}_{13} \mathrm{H}_{13} \mathrm{NOS} 231.0718$, found 231.0719.

2-Formyl-5-biphenyl-thiophene 5g was obtained as a yellow solid (98 mg, 31\%). Mp 192.9193.8 ${ }^{\circ} \mathrm{C} .{ }^{1} \mathrm{H} \mathrm{NMR}\left(\mathrm{CDCl}_{3}\right): \delta=7.34-7.84(\mathrm{~m}, 11 \mathrm{H}, 3,4-\mathrm{H}$ and $9 \times \mathrm{Ar}-H), 9.90(\mathrm{~s}, 1 \mathrm{H}, \mathrm{CHO})$ ppm. ${ }^{13} \mathrm{C} \mathrm{NMR}\left(\mathrm{CDCl}_{3}\right): \delta=124.03,126.78,126.93,127.76,127.83,128.91,131.89,137.48$, $139.93,142.19,142.35,153.89,182.75 \mathrm{ppm}$. IR (nujol): $v=1658(\mathrm{~s}) \mathrm{cm}^{-1} . \mathrm{MS}(\mathrm{EI}): \mathrm{m} / z(\%)=$ 264 ( $\left.\mathrm{M}^{+}, 67\right), 207$ (100). EI-HRMS: calcd. for $\mathrm{C}_{17} \mathrm{H}_{12} \mathrm{OS} 264.0609$, found 264.0598.

2-Formyl-5-phenoxyphenyl-thiophene $5 \mathrm{~h}$ was obtained as a yellow solid (87 $\mathrm{mg}, 26 \%)$. Mp 82.6-83.7 ${ }^{\circ} \mathrm{C} .{ }^{1} \mathrm{H} \mathrm{NMR}\left(\mathrm{CDCl}_{3}\right): \delta=7.02-7.10(\mathrm{~m}, 4 \mathrm{H}, 4 \times \mathrm{Ar}-H), 7.13-7.20(\mathrm{br} \mathrm{t}, J=7.5 \mathrm{~Hz}$, $1 \mathrm{H}, \operatorname{Ar}-H), 7.33(\mathrm{~d}, J=4.2 \mathrm{~Hz}, 1 \mathrm{H}, 4-\mathrm{H}), 7.35$ (br t, $J=7.5 \mathrm{~Hz}, 2 \mathrm{H}, 2 \times \mathrm{Ar}-H), 7.64(\mathrm{~d}, J=$ $8.7 \mathrm{~Hz}, 2 \mathrm{H}, 2 \times \mathrm{Ar}-H), 7.73(\mathrm{~d}, J=4.2 \mathrm{~Hz}, 1 \mathrm{H}, 3-\mathrm{H}), 9.88(\mathrm{~s}, 1 \mathrm{H}, \mathrm{CHO}) \mathrm{ppm} .{ }^{13} \mathrm{C} \mathrm{NMR}$ $\left(\mathrm{CDCl}_{3}\right): \delta=118.81,119.53,123.54,124.07,127.84,127.96,129.94,137.62,141.96,153.87$, 156.18, 158.76, 182.74 ppm. IR (nujol): $v=1653$ (s) $\mathrm{cm}^{-1} \cdot \mathrm{C}_{17} \mathrm{H}_{12} \mathrm{O}_{2} \mathrm{~S}$ (280.35): calcd. $\mathrm{C}$ 72.84, H 4.28, S 11.45; found C 72.86, H 4.33, S 11.40. 
2-Formyl-5-naphthyl-thiophene 5 i was obtained as a yellow oil (254 mg, 89\%). [lit. ${ }^{[11]} 72$ $73{ }^{\circ} \mathrm{C}\left(\mathrm{EtOH}\right.$ and benzene)]. ${ }^{1} \mathrm{H} \mathrm{NMR}\left(\mathrm{CDCl}_{3}\right): \delta=7.36(\mathrm{~d}, J=3.9 \mathrm{~Hz}, 1 \mathrm{H}, 4-\mathrm{H}), 7.50-7.64$ $(\mathrm{m}, 4 \mathrm{H}, 4 \times \mathrm{Ar}-H), 7.85(\mathrm{~d}, J=3.9 \mathrm{~Hz}, 1 \mathrm{H}, 3-\mathrm{H}), 7.90-8.00(\mathrm{~m}, 2 \mathrm{H}, 2 \times \mathrm{Ar}-H), 8.14-8.20$ (m, $1 \mathrm{H}, \mathrm{Ar}-H), 9.97(\mathrm{~s}, 1 \mathrm{H}, \mathrm{CHO}) \mathrm{ppm} .{ }^{13} \mathrm{C} \mathrm{NMR}\left(\mathrm{CDCl}_{3}\right): \delta=125.01,125.16,126.34,126.99$, 128.27, 128.52, 128.58, 129.72, 130.99, 131.04, 133.73, 136.62, 143.44, 152.24, 182.91 ppm. IR (nujol): $v=1666(\mathrm{~s}) \mathrm{cm}^{-1}$. MS (EI): $m / z(\%)=238\left(\mathrm{M}^{+}, 100\right)$. EI-HRMS: calcd. for $\mathrm{C}_{15} \mathrm{H}_{10} \mathrm{OS} 238.0452$, found 238.0444 .

2-Formyl-5-(4'-fluorophenyl)-thiophene 5j was obtained as a yellow solid (47 $\mathrm{mg}, 19 \%)$. Mp 113.2-114.0 ${ }^{\circ} \mathrm{C}$ [lit. ${ }^{[12]} \mathrm{mp}$ not quoted]. ${ }^{1} \mathrm{H} \mathrm{NMR}\left(\mathrm{CDCl}_{3}\right): \delta=7.14\left(\mathrm{t}, J_{\mathrm{H}-\mathrm{F}}=8.4 \mathrm{~Hz}, 2 \mathrm{H}\right.$, 3' and 5'-H), $7.35(\mathrm{~d}, J=3.9 \mathrm{~Hz}, 1 \mathrm{H}, 4-\mathrm{H}), 7.63-7.68\left(\mathrm{~m}, 2 \mathrm{H}, 2^{\prime}\right.$ and 6'-H), $7.75(\mathrm{~d}, J=3.9$ $\mathrm{Hz}, 1 \mathrm{H}, 3-\mathrm{H}), 9.90(\mathrm{~s}, 1 \mathrm{H}, \mathrm{CHO}) \mathrm{ppm} .{ }^{13} \mathrm{C} \mathrm{NMR}\left(\mathrm{CDCl}_{3}\right): \delta=116.29\left(\mathrm{~d}, J_{\mathrm{C}-\mathrm{F}}=22.1 \mathrm{~Hz}, \mathrm{C} 3\right.$ ' and C5'), 124.06 (C4), 128.27 (d, $J_{\mathrm{C}-\mathrm{F}}=8.4 \mathrm{~Hz}, \mathrm{C} 2$ ' and C6'), 129.40 (d, $J_{\mathrm{C}-\mathrm{F}}=3.9 \mathrm{~Hz}, \mathrm{C}^{\prime}$ '), 137.41 (C3), 142.51 (C2), 153.03 (C5), 163.38 (d, J J-F $=250$ Hz, C4'), 182.73 (CHO) ppm. IR (KBr): $v=1641(\mathrm{~s}) \mathrm{cm}^{-1}$. MS (EI): $m / z(\%)=206\left(\mathrm{M}^{+}, 85\right), 205$ (100). EI-HRMS: calcd. for $\mathrm{C}_{11} \mathrm{H}_{7} \mathrm{FOS}$ 206.0202, found 206.0209.

2-Formyl-5-(4'-formylphenyl)-thiophene 5k was obtained as a yellow solid (220 mg, 85\%).

Mp 145.3-146.1 ${ }^{\circ} \mathrm{C} .{ }^{1} \mathrm{H}$ NMR $\left(\mathrm{CDCl}_{3}\right): \delta=7.54(\mathrm{~d}, J=4.2 \mathrm{~Hz}, 1 \mathrm{H}, 4-\mathrm{H}), 7.79(\mathrm{~d}, J=4.2 \mathrm{~Hz}$, $1 \mathrm{H}, 3-\mathrm{H}), 7.84\left(\mathrm{~d}, J=8.4 \mathrm{~Hz}, 2 \mathrm{H}, 2^{\prime}\right.$ and 6'-H), 7.96 (d, $J=8.4 \mathrm{~Hz}, 2 \mathrm{H}, 3^{\prime}$ and 5'-H), 9.93 (s, $1 \mathrm{H}, \mathrm{CHO}), 10.05$ (s, $1 \mathrm{H}, \mathrm{CHO}) \mathrm{ppm} .{ }^{13} \mathrm{C} \mathrm{NMR}\left(\mathrm{CDCl}_{3}\right): \delta=125.70,126.78,130.48,136.41$, 137.13, 138.49, 143.86, 151.78, 182.76, 191.20 ppm. IR (nujol): $v=1696$ (s), 1654 (s) cm $\mathrm{cm}^{-1}$. MS (EI): $m / z(\%)=216\left(\mathrm{M}^{+}, 98\right), 215$ (100). EI-HRMS: calcd. for $\mathrm{C}_{12} \mathrm{H}_{8} \mathrm{O}_{2} \mathrm{~S} 216.0245$, found 216.0242 .

\section{General procedure for the syntheses of benzothiazoles 6}

The corresponding formylarylthiophenes $\mathbf{5}$ and $o$-aminobenzenethiol (1.1 eq) were heated in DMSO $(0.5 \mathrm{~mL} / \mathrm{mmol})$ at $120{ }^{\circ} \mathrm{C}$ with stirring for 30-60 min. The reaction was followed by TLC using chloroform/ hexane 1:1 as eluent. When the reaction was complete, the reaction mixture was allowed to cool and poured into water and extracted with ethyl acetate $(3 \times 30$ $\mathrm{mL} / \mathrm{mmol})$. The organic layer was dried with magnesium sulphate and evaporated under 
vacuum. The crude residue was submitted to silica gel column chromatography using mixtures of hexane and chloroform of increasing polarity. The fractions containing the purified product were collected and evaporated under vacuum.

2-(4'-(2''-Thienyl)-phenyl)-1,3-benzothiazole 6a was obtained as a yellow solid (299 mg, 85\%). Mp 205.5-206.1 ${ }^{\circ} \mathrm{C} .{ }^{1} \mathrm{H}$ NMR $\left(\mathrm{CDCl}_{3}\right): \delta=7.14-7.20$ (m, $\left.1 \mathrm{H}, 4{ }^{\prime}{ }^{-}-\mathrm{H}\right), 7.36(\mathrm{dd}, J=5.1$, $1.2 \mathrm{~Hz}, 1 \mathrm{H}, 5$ ' '-H), 7.40 (dt, $J=7.2,1.2 \mathrm{~Hz}, 1 \mathrm{H}, 6-\mathrm{H}), 7.44$ (dd, $J=3.6,1.2 \mathrm{~Hz}, 1 \mathrm{H}, 3$ ''-H), $7.51(\mathrm{dt}, J=7.2,1.2 \mathrm{~Hz}, 1 \mathrm{H}, 5-\mathrm{H}), 7.74\left(\mathrm{~d}, J=8.8 \mathrm{~Hz}, 2 \mathrm{H}, 3^{\prime}\right.$ and $\left.5^{\prime}-\mathrm{H}\right), 7.92(\mathrm{dd}, J=7.2,1.2$ Hz, 1H, 7-H), 8.09 (dd, $J=7.2,1.2 \mathrm{~Hz}, 1 \mathrm{H}, 4-\mathrm{H}), 8.11$ (d, $J=8.8 \mathrm{~Hz}, 2 \mathrm{H}, 2$ ' and 6'-H) ppm.

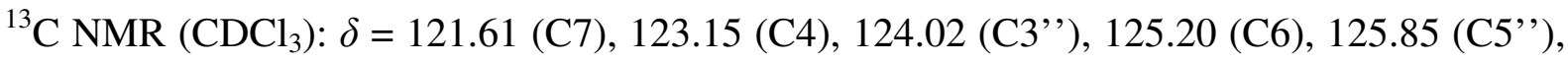
126.17 (C3' and C5'), 126.37 (C5), 128.06 (C2' and C6'), 128.28 (C4'’), 132.40 (C1'), 134.97 (C7a), 136.81 (C4'), 143.26 (C2'’), 154.15 (C3a), 167.43 (C2) ppm. IR (KBr): v = 1602, 1479, 1425, 1315, 1250, 1115, 965, 816, 757, $692 \mathrm{~cm}^{-1} \cdot \mathrm{C}_{17} \mathrm{H}_{11} \mathrm{NS}_{2}$ (293.41): calcd. C 69.59, H 3.78, N 4.77, S 21.85; found C 69.53, H 3.91, N 4.84, S 21.54.

2-(5'-(4''-Methoxyphenyl)-2'-thienyl)-1,3-benzothiazole $6 \mathbf{b}$ was obtained as a yellow solid (333 mg, 86\%). Mp 154.3-155.7 ${ }^{\circ} \mathrm{C} .{ }^{1} \mathrm{H}$ NMR $\left(\mathrm{CDCl}_{3}\right): \delta=3.86\left(\mathrm{~s}, 3 \mathrm{H}, \mathrm{OCH}_{3}\right), 6.96(\mathrm{~d}, J=$ $8.7 \mathrm{~Hz}, 2 \mathrm{H}, 3$ ' ' and 5' -H), $7.22\left(\mathrm{~d}, J=3.3 \mathrm{~Hz}, 1 \mathrm{H}, 4^{\prime}-\mathrm{H}\right), 7.37(\mathrm{dt}, J=7.8,1.2 \mathrm{~Hz}, 1 \mathrm{H}, 6-\mathrm{H})$, $7.48(\mathrm{dt}, J=7.8,1.2 \mathrm{~Hz}, 1 \mathrm{H}, 5-\mathrm{H}), 7.61(\mathrm{~m}, 3 \mathrm{H}, 3$ ', 2'" and 6"'-H), $7.84(\mathrm{dd}, J=7.8,1.2 \mathrm{~Hz}$, $1 \mathrm{H}, 7-\mathrm{H}), 8.02(\mathrm{dd}, J=7.8,1.2 \mathrm{~Hz}, 1 \mathrm{H}, 4-\mathrm{H}) \mathrm{ppm} .{ }^{13} \mathrm{C} \mathrm{NMR}\left(\mathrm{CDCl}_{3}\right): \delta=55.37\left(\mathrm{OCH}_{3}\right)$, 114.47 (C3', and C5'), 121.38 (C7), 122.77 (C4), 122.79 (C4'), 125.04 (C6), 126.31 (C1' '), 126.39 (C5), 127.26 (C2' ' and C6'), 129.59 (C3'), 134.57 (C7a), 135.01 (C2'), 148.28 (C5'), 153.71 (C3a), 159.93 (C4'’), 161.36 (C2) ppm. IR (KBr): v = 1604, 1544, 1481, 1443, 1431, 1250, 1178, 1023, 904, 830, 794, 735, $724 \mathrm{~cm}^{-1}$. MS (EI): $\mathrm{m} / z(\%)=323\left(\mathrm{M}^{+}, 100\right), 308(55)$. EI-HRMS: calcd. for $\mathrm{C}_{18} \mathrm{H}_{13} \mathrm{NOS}_{2}$ 323.0439, found 323.0437.

2-(5'-(2',4'’-Dimethoxyphenyl)-2'-thienyl)-1,3-benzothiazole 6c was obtained as a yellow solid (127 mg, 30\%). Mp 108.0-111.0 ${ }^{\circ} \mathrm{C} .{ }^{1} \mathrm{H}$ NMR (DMSO-d $\left.\mathrm{d}_{6}\right): \delta=3.83$ (s, 3H, $\mathrm{OCH}_{3}$ ), 3.98 (s, 3H, $\left.\mathrm{OCH}_{3}\right), 6.66\left(\mathrm{dd}, J=8.4,2.1 \mathrm{~Hz}, 1 \mathrm{H}, 5^{\prime}\right.$ ' $\left.-\mathrm{H}\right), 6.74$ (d, $J=2.1 \mathrm{~Hz}, 1 \mathrm{H}, 3$ ' ' -H), 7.42 (dt, $J=8.1,0.9 \mathrm{~Hz}, 1 \mathrm{H}, 6-\mathrm{H}), 7.51(\mathrm{dt}, J=8.1,0.9 \mathrm{~Hz}, 1 \mathrm{H}, 5-\mathrm{H}), 7.62\left(\mathrm{~d}, J=3.9 \mathrm{~Hz}, 1 \mathrm{H}, 4^{\prime}-\mathrm{H}\right)$, 7.78 (d, $\left.J=3.9 \mathrm{~Hz}, 1 \mathrm{H}, 3^{\prime}-\mathrm{H}\right), 7.81$ (d, $J=8.4 \mathrm{~Hz}, 1 \mathrm{H}, 6$ ''-H), 7.97 (dd, $J=8.1,0.9 \mathrm{~Hz}, 1 \mathrm{H}$, 4-H), $8.08(\mathrm{dd}, J=8.1,0.9 \mathrm{~Hz}, 1 \mathrm{H}, 7-\mathrm{H}) \mathrm{ppm} .{ }^{13} \mathrm{C} \mathrm{NMR}\left(\mathrm{CDCl}_{3}\right): \delta=55.49\left(\mathrm{OCH}_{3}\right), 55.60$ 
$\left(\mathrm{OCH}_{3}\right), 98.88$ (C5’), 105.38 (C3’'), 115.66 (C1’’), 121.33 (C7), 122.69 (C4), 124.57 (C4'), 124.84 (C6), 126.27 (C5), 128.59 (C3'), 128.99 (C6’'), 134.55 (C7a), 135.07 (C2'), 143.95 (C5'), 153.87 (C3a), 157.05 (C4' or C2'), 160.95 (C4'” or C2'), 161.96 (C2) ppm. IR $(\mathrm{KBr}): v=2961,2928,2849,1605,1515,1470,1447,1313,1246,1021,835,740 \mathrm{~cm}^{-1}$. MS (EI): $m / z(\%)=353\left(\mathrm{M}^{+}, 100\right), 338$ (42). EI-HRMS: calcd. for $\mathrm{C}_{19} \mathrm{H}_{15} \mathrm{NO}_{2} \mathrm{~S}_{2} 353.0544$, found 353.0530 .

2-(5'-(4'-Ethoxyphenyl)-2'-thienyl)-1,3-benzothiazole 6d was obtained as a yellow solid (335 mg, 83\%). Mp 147.5-148.9 ${ }^{\circ} \mathrm{C} .{ }^{1} \mathrm{H} \mathrm{NMR}\left(\mathrm{CDCl}_{3}\right): \delta=1.45\left(\mathrm{t}, J=6.9 \mathrm{~Hz}, 3 \mathrm{H}, \mathrm{CH}_{3}\right), 4.85$ (q, $\left.J=6.9 \mathrm{~Hz}, 2 \mathrm{H}, \mathrm{CH}_{2}\right), 6.95(\mathrm{~d}, J=8.7 \mathrm{~Hz}, 2 \mathrm{H}, 3$ ' ' and 5' '-H), 7.04 (d, $J=3.6 \mathrm{~Hz}, 1 \mathrm{H}, 4$ 'H), 7.36 (dt, $J=7.5,1.2 \mathrm{~Hz}, 1 \mathrm{H}, 6-\mathrm{H}), 7.48$ (dt, $J=7.5,1.2 \mathrm{~Hz}, 1 \mathrm{H}, 5-\mathrm{H}), 7.60$ (m, 3H, 3', 2', and 6' $-\mathrm{H}), 7.85(\mathrm{dd}, J=7.5,1.2 \mathrm{~Hz}, 1 \mathrm{H}, 7-\mathrm{H}), 8.04(\mathrm{dd}, J=7.5,1.2 \mathrm{~Hz}, 1 \mathrm{H}, 4-\mathrm{H}) \mathrm{ppm} .{ }^{13} \mathrm{C}$ $\operatorname{NMR}\left(\mathrm{CDCl}_{3}\right): \delta=14.76\left(\mathrm{CH}_{3}\right), 63.58\left(\mathrm{CH}_{2}\right), 114.98\left(\mathrm{C}^{\prime}{ }^{\prime}\right.$ ' and C5' $), 121.38(\mathrm{C} 7), 122.71$ (C4'), 122.76 (C4), 125.03 (C5), 126.13 (C1'), 126.38 (C6), 127.24 (C2'” and C6'), 129.59 (C3'), 134.56 (C7a), 134.93 (C2'), 148.38 (C5'), 153.72 (C3a), 159.32 (C4’'), 161.38 (C2) ppm. IR (KBr): $v=3000,2990,1596,1546,1483,1446,1390,1251,1184,1117,1081$, $1047,901,830,789,754,731 \mathrm{~cm}^{-1} . \mathrm{MS}(\mathrm{EI}): \mathrm{m} / z(\%)=337\left(\mathrm{M}^{+}, 100\right), 309$ (72), 308 (79). EIHRMS: calcd. for $\mathrm{C}_{19} \mathrm{H}_{15} \mathrm{NOS}_{2} 337.0595$, found 337.0607 .

2-(5'-(4'-Hydroxyphenyl)-2'-thienyl)-1,3-benzothiazole 6e was obtained as a light brown solid (148 mg, 40\%). Mp 212.4-213.5 ${ }^{\circ} \mathrm{C} .{ }^{1} \mathrm{H} \mathrm{NMR}\left(\mathrm{CDCl}_{3}\right): \delta=6.82(\mathrm{~d}, J=9.0 \mathrm{~Hz}, 2 \mathrm{H}, 3$, and 5' '-H), $7.11\left(\mathrm{~d}, J=3.9 \mathrm{~Hz}, 1 \mathrm{H}, 4^{\prime}-\mathrm{H}\right), 7.27(\mathrm{dt}, J=7.8,1.2 \mathrm{~Hz}, 1 \mathrm{H}, 6-\mathrm{H}), 7.38$ (dt, $J=$ 7.8, 1.2 Hz, 1H, 5-H), 7.42 (d, $J=9.0 \mathrm{~Hz}, 2 \mathrm{H}, 2$ '” and 6' $-\mathrm{H}), 7.50\left(\mathrm{~d}, J=3.9 \mathrm{~Hz}, 1 \mathrm{H}, 3^{\prime}-\mathrm{H}\right)$, $7.76(\mathrm{dd}, J=7.8,1.2 \mathrm{~Hz}, 1 \mathrm{H}, 7-\mathrm{H}), 7.90$ (dd, $J=7.8,1.2 \mathrm{~Hz}, 1 \mathrm{H}, 4-\mathrm{H}), 9.03$ (br s, 1H, OH) ppm. ${ }^{13} \mathrm{C} \mathrm{NMR}\left(\mathrm{CDCl}_{3}\right): \delta=115.94$ (C3', and C5',), 121.18 (C7), 122.10 (C4'), 122.37 (C4), 124.63 (C1',), 124.78 (C6), 126.14 (C5), 127.05 (C2'” and C6'), 129.47 (C3'), 134.09 (C7a), 134.25 (C2'), 148.74 (C5'), 153.42 (C3a), 157.87 (C4'”), 161.20 (C2) ppm. IR (KBr): v = 3500-3000 (OH), 1608, 1587, 1544, 1310, 1260, 1177, 1107, 1020, 910, 830, 799, 755, 730, $518 \mathrm{~cm}^{-1}$. MS (EI): $m / z(\%)=309\left(\mathrm{M}^{+}, 100\right)$. EI-HRMS: calcd. for $\mathrm{C}_{17} \mathrm{H}_{11} \mathrm{NOS}_{2} 309.0282$, found 309.0290 . 
2-(5'-(4' $-N, N$-Dimethylaminophenyl)-2'-thienyl)-1,3-benzothiazole 6 f was obtained as an orange solid (197 mg, 49\%). Mp 210.8-211.5 ${ }^{\circ} \mathrm{C} .{ }^{1} \mathrm{H}$ NMR $\left(\mathrm{CDCl}_{3}\right): \delta=3.03$ (s, 6H, $\left.\mathrm{N}\left(\mathrm{CH}_{3}\right)_{2}\right), 6.74(\mathrm{~d}, J=9 \mathrm{~Hz}, 2 \mathrm{H}, 3$ ' ' and 5' '-H), 7.19 (d, $J=3.9 \mathrm{~Hz}, 1 \mathrm{H}, 4$ '-H), 7.35 (dt, $J=$ 7.5, 1.2 Hz, 1H, 6-H), 7.47 (dt, $J=7.5,1.2 \mathrm{~Hz}, 1 \mathrm{H}, 5-\mathrm{H}), 7.56$ (d, $J=9 \mathrm{~Hz}, 2 \mathrm{H}, 2$ ' ' and 6' H), 7.59 (d, $J=3.9 \mathrm{~Hz}, 1 \mathrm{H}, 3$ '-H), 7.84 (dd, $J=7.5,1.2 \mathrm{~Hz}, 1 \mathrm{H}, 7-\mathrm{H}), 8.01$ (dd, $J=7.5,1.2$ $\mathrm{Hz}, 1 \mathrm{H}, 4-\mathrm{H}) \mathrm{ppm} .{ }^{13} \mathrm{C} \mathrm{NMR}\left(\mathrm{CDCl}_{3}\right): \delta=40.32\left(\mathrm{CH}_{3}\right), 112.35$ (C3'” and C5' '), $121.34(\mathrm{C} 7)$, 121.45 (C4'), 121.64 (C1',), 122.63 (C4), 124.86 (C6), 126.31 (C5), 126.97 (C2', and C6'), 129.79 (C3'), 133.59 (C2'), 134.51 (C7a), 149.60 (C5'), 150.55 (C4'’), 153.79 (C3a), 161.65 (C2) ppm. IR (KBr): $v=1609,1543,1481,1441,1363,1230,1194,800 \mathrm{~cm}^{-1} . \mathrm{MS}(\mathrm{EI}): \mathrm{m} / z$ $(\%)=336\left(\mathrm{M}^{+}, 100\right)$. EI-HRMS: calcd. for $\mathrm{C}_{19} \mathrm{H}_{16} \mathrm{~N}_{2} \mathrm{~S}_{2} 336.0755$, found 336.0758.

2-(5'-(Biphenyl-2'-thienyl)-1,3-benzothiazole 6g was obtained as an orange solid (394 mg, 89\%). Mp 232.5-233.6 ${ }^{\circ} \mathrm{C} .{ }^{1} \mathrm{H}$ NMR $\left(\mathrm{CDCl}_{3}\right): \delta=7.26-7.34$ (m, 3H, 6, 4' and 4','-H), 7.34$7.44(\mathrm{~m}, 3 \mathrm{H}, 5,3$ ', ' and 5','-H), 7.52-7.62 (m, 5H, 3', 3', 5', 2',' and 6'"'-H), 7.70 (d, $J=$ $8.4 \mathrm{~Hz}, 2 \mathrm{H}, 2$ "' and 6"'-H), 7.79 (br d, $J=8.1 \mathrm{~Hz}, 1 \mathrm{H}, 7-\mathrm{H}), 7.94$ (br d, $J=8.1 \mathrm{~Hz}, 1 \mathrm{H}, 4-\mathrm{H}$ ) ppm. ${ }^{13} \mathrm{C} \mathrm{NMR}\left(\mathrm{CDCl}_{3}\right): \delta=121.26$ (C7), 122.57 (C4), 123.73 (C4'), 125.01 (C6), 126.05 (C2' ' and 6' '), 126.26 (C5), 126.64 (C2'”' and 6','), 127.42 (C4','), 127.46 (C3' and 5'), 128.66 (C3',' and 5','), 129.41 (C3'), 132.16 (C1'’), 134.38 (C7a), 135.81 (C2'), 139.88 (C1','), 140.93 (C4’'), 147.47 (C5'), 153.43 (C3a), 160.90 (C2) ppm. IR (KBr): v = 1479, $1443,902,801,754 \mathrm{~cm}^{-1}$. MS (EI): $\mathrm{m} / z(\%)=369\left(\mathrm{M}^{+}, 100\right)$. EI-HRMS: calcd. for $\mathrm{C}_{23} \mathrm{H}_{15} \mathrm{NS}_{2}$ 369.0646, found 369.0648 .

2-(5'-(Phenoxyphenyl)-2'-thienyl)-1,3-benzothiazole 6h was obtained as a yellow solid (420 mg, 91\%). Mp 170.4-171.8 ${ }^{\circ} \mathrm{C} .{ }^{1} \mathrm{H}$ NMR $\left(\mathrm{CDCl}_{3}\right): \delta=7.02$ (m, 4H, 3', 5', 3',' and 5','-H), 7.17 (dt, $J=7.8,1.2 \mathrm{~Hz}, 1 \mathrm{H}, 4$ ','-H), 7.26 (d, $J=4.0 \mathrm{~Hz}, 1 \mathrm{H}, 4$ '-H), 7.34-7.42 (m, $3 \mathrm{H}, 6,2$ ', and 6"' $-\mathrm{H}), 7.48(\mathrm{dt}, J=7.8,1.2 \mathrm{~Hz}, 1 \mathrm{H}, 5-\mathrm{H}), 7.61(\mathrm{~d}, J=4.0 \mathrm{~Hz}, 1 \mathrm{H}, 3$ '-H), 7.64 (d, $J=7.8 \mathrm{~Hz}, 2 \mathrm{H}, 2$ ' ' and 6'-H), $7.86(\mathrm{dd}, J=7.8,1.2 \mathrm{~Hz}, 1 \mathrm{H}, 7-\mathrm{H}), 8.04$ (dd, $J=7.8,1.2$ $\mathrm{Hz}, 1 \mathrm{H}, 4-\mathrm{H}) \mathrm{ppm} .{ }^{13} \mathrm{C} \mathrm{NMR}\left(\mathrm{CDCl}_{3}\right): \delta=118.97$ (C3', and C5',), 119.32 (C3',' and C5','), 121.40 (C7), 122.82 (C4), 123.38 (C4'), 123.78 (C4'’'), 125.13 (C6), 126.43 (C5), 127.40 (C2' and C6'), 128.51 (C1'”), 129.55 (C3'), 129.87 (C2'”' and C6'”), 134.59 (C7a), 135.61 (C2'), 147.66 (C5'), 153.68 (C3a), 156.54 (C1'’'), 157.84 (C4’’), 161.21 (C2) ppm. IR (KBr): $v=3050,1587,1547,1510,1489,1481,1444,1434,1312,1281,1254,1174,1161,1113$, 
1073, 1013, 905, 874, 843, 802, 747, 727, $690 \mathrm{~cm}^{-1}$. MS (EI): $\mathrm{m} / z(\%)=385\left(\mathrm{M}^{+}, 100\right)$. EIHRMS: calcd. for $\mathrm{C}_{23} \mathrm{H}_{15} \mathrm{NOS}_{2} 385.0595$, found 385.0590 .

2-(5'-(1'-Naphtyl)-2'-thienyl)-1,3-benzothiazole 6i was obtained as a yellow solid (316 mg, 77\%). Mp 157.9-158.8 ${ }^{\circ} \mathrm{C} .{ }^{1} \mathrm{H} \mathrm{NMR}\left(\mathrm{CDCl}_{3}\right): \delta=7.31$ (d, $\left.J=3.6 \mathrm{~Hz}, 1 \mathrm{H}, 4^{\prime}-\mathrm{H}\right), 7.39$ (dt, $J=$ 7.5, $1.2 \mathrm{~Hz}, 1 \mathrm{H}, 6-\mathrm{H}), 7.50$ (dt, $J=7.5,1.2 \mathrm{~Hz}, 1 \mathrm{H}, 5-\mathrm{H}), 7.52$ (m, 3H, Ar), 7.64 (dd, $J=7.5$, $1.2 \mathrm{~Hz}, 1 \mathrm{H}, 2$ ' '-H), 7.75 (d, $J=3.6 \mathrm{~Hz}, 1 \mathrm{H}, 3$ '-H), 7.87-7.96 (m, 3H, 7-H and Ar- $H$ ), 8.04 (dd, $J=7.5,1.2 \mathrm{~Hz}, 1 \mathrm{H}, 4-\mathrm{H}), 8.30-8.36$ (m, $1 \mathrm{H}, \mathrm{Ar}) \mathrm{ppm} .{ }^{13} \mathrm{C} \mathrm{NMR}\left(\mathrm{CDCl}_{3}\right): \delta=121.45(\mathrm{C} 7)$, 122.93 (C4), 125.20 (C6), 125.29, 125.45, 126.23 (naph), 126.45 (C5), 126.79, 128.19 (naph), 128.33 (C4'), 128.46 (naph), 128.81 (C3'), 129.14 (naph), 131.40 (C1'), 131.49 (C5'), 133.88 (C10'), 134.67 (C7a), 137.15 (C2'), 146.05 (C5'), 153.75 (C3a), 161.29 (C2) ppm. IR $(\mathrm{KBr}): v=1545,1492,1432,1391,1312,1231,900,796,761,729 \mathrm{~cm}^{-1} . \mathrm{MS}(\mathrm{EI}): \mathrm{m} / z(\%)=$ $343\left(\mathrm{M}^{+}, 100\right)$. EI-HRMS: calcd. for $\mathrm{C}_{21} \mathrm{H}_{13} \mathrm{NS}_{2} 343.0489$, found 343.0479.

2-(5'-(4'-Fluorophenyl)-2'-thienyl)-1,3-benzothiazole $\mathbf{6 j}$ was obtained as a yellow solid (336 mg, 90\%). Mp 165.2-167.9 ${ }^{\circ} \mathrm{C} .{ }^{1} \mathrm{H} \mathrm{NMR}\left(\mathrm{CDCl}_{3}\right): \delta=7.12\left(\mathrm{t}, J_{\mathrm{H}-\mathrm{F}}=9.0 \mathrm{~Hz}, 2 \mathrm{H}, 3^{\prime \prime}\right.$, and 5' -H), 7.25 (d, $J=3.9 \mathrm{~Hz}, 1 \mathrm{H}, 4$ '-H), 7.37 (dt, $J=8.0,1.2 \mathrm{~Hz}, 1 \mathrm{H}, 6-\mathrm{H}), 7.50$ (dt, $J=8.0,1.2$ Hz, 1H, 5-H), 7.59 (d, $J=3.9 \mathrm{~Hz}, 1 \mathrm{H}, 3$ '-H), 7.60-7.65 (m, 2H, 2', and 6' '-H), 7.86 (dd, $J=$ 8.0, $1.2 \mathrm{~Hz}, 1 \mathrm{H}, 7-\mathrm{H}), 8.04(\mathrm{dd}, J=8.0,1.2 \mathrm{~Hz}, 1 \mathrm{H}, 4-\mathrm{H}) \mathrm{ppm} .{ }^{13} \mathrm{C} \mathrm{NMR}\left(\mathrm{CDCl}_{3}\right): \delta=116.11$ (d, $J_{\mathrm{C}-\mathrm{F}}=21.9 \mathrm{~Hz}, \mathrm{C} 3$ ' ' and C5'), 121.42 (C7), 122.87 (C4), 123.82 (C4'), 125.21 (C6), 126.46 (C5), 126.67 (d, $J_{\mathrm{C}-\mathrm{F}}=8.4 \mathrm{~Hz}, \mathrm{C} 2$ ' ' and C6' '), 129.46 (C3'), 129.80 (d, $J_{\mathrm{C}-\mathrm{F}}=3.8 \mathrm{~Hz}$, C1'”), 134.61 (C7a), 136.13 (C2'), 146.92 (C5'), 153.65 (C3a), 161.06 (C2), 162.79 (d, $J_{\mathrm{C}-\mathrm{F}}=$ $250 \mathrm{~Hz}, \mathrm{C4}$ ') $)$ ppm. IR (KBr): $v=1597,1547,1514,1484,1446,1434,1310,1258,1229$, $1164,1015,905,801,755,729,703,622,604,533 \mathrm{~cm}^{-1}$. MS (EI): $\mathrm{m} / z(\%)=311\left(\mathrm{M}^{+}, 100\right)$. EI-HRMS: calcd. for $\mathrm{C}_{17} \mathrm{H}_{10} \mathrm{NS}_{2} \mathrm{~F} 311.0239$, found 311.0240.

2,2'-[5"'-(4"'-Phenyl)thienyl]-bis-1,3-benzothiazole 6k was obtained as a yellow solid (429 mg, 84\%). Mp 255.9-256.7 ${ }^{\circ} \mathrm{C} .{ }^{1} \mathrm{H}$ NMR $\left(\mathrm{CDCl}_{3}\right): \delta=7.36-7.45$ (m, 2H, 6 and 6'-H), 7.47 (d, $J=3.9 \mathrm{~Hz}, 1 \mathrm{H}, 4$ ''-H), 7.48-7.56 (m, 2H, 5 and 5'-H), 7.68 (d, $J=3.9 \mathrm{~Hz}, 1 \mathrm{H}, 3$ '’-H), 7.81 (dd, $J=8.4,1.8 \mathrm{~Hz}, 2 \mathrm{H}, 2$ ', ' and 6" ' $-\mathrm{H}), 7.88$ (dd, $\left.J=8.1,1.1 \mathrm{~Hz}, 1 \mathrm{H}, 7{ }^{\prime}-\mathrm{H}\right), 7.93$ (dd, $J=$ $8.1,1.1 \mathrm{~Hz}, 1 \mathrm{H}, 7-\mathrm{H}), 8.06$ (dd, $J=8.1,1.1 \mathrm{~Hz}, 1 \mathrm{H}, 4$ '-H), 8.11 (dd, $J=8.1,1.1 \mathrm{~Hz}, 1 \mathrm{H}, 4-\mathrm{H})$, $8.17\left(\mathrm{dd}, J=8.4,1.8 \mathrm{~Hz}, 2 \mathrm{H}, 3{ }^{\prime \prime \prime}\right.$ and $\left.5{ }^{\prime \prime \prime}-\mathrm{H}\right) \mathrm{ppm} .{ }^{13} \mathrm{C} \mathrm{NMR}\left(\mathrm{CDCl}_{3}\right): \delta=121.5\left(\mathrm{C} 7^{\prime}\right), 121.7$ 
(C7), 123.1 (C4'), 123.3 (C4), 124.8 (C4'’), 125.4 (C6 and C6'), 126.3 (C2',' and C6','), 126.5 (C5'), 126.6 (C5), 128.3 (C3', and C5','), 129.5 (C3'”), 133.5 (C4'”), 134.8 (C7a'), 135.9 (C7a), 137.1 (C2’’), 146.9 (C5’'), 153.8 (C3a'), 154.3 (C3a), 160.9 (C1'”'), 161.1 (C2), 167.1 (C2') ppm. IR (KBr): $v=3049,1602,1547,1484,1477,1444,1313,1256,1230,1185$, $1115,1063,1015,961,904,833,802,755,728,701,619 \mathrm{~cm}^{-1}$. MS (EI): $\mathrm{m} / z(\%)=426\left(\mathrm{M}^{+}\right.$, 100). EI-HRMS: calcd. for $\mathrm{C}_{24} \mathrm{H}_{14} \mathrm{~N}_{2} \mathrm{~S}_{3} 426.0319$, found 426.0334 .

\section{Acknowledgements}

Thanks are due to Foundation for Science and Technology (Portugal) for financial support through Centro de Química (Univ. Minho). The authors are also grateful to Dr. H. Figueiredo and Prof. I. C. Neves of the Department of Chemistry of the University of Minho for the thermo gravimetric analyses.

\section{References}

${ }^{[1]}{ }^{11 \mathrm{a}]}$ D. S. Zyss In: Non linear optical properties of organic molecules and crystals, Vol 1 and 2; Academic Press: Orlando, 1987. ${ }^{[1 \mathrm{~b}]}$ C. Brosshard, K. Sutter, P. Petre, J. Hulliger, M. Florsheimer, M. Kaatz, P. Gunter In: Organic non-linear optical materials, Gordon and Breach Science Publishers: Amsterdam, 1995.

${ }^{[2] ~[2 a]}$ C. W. Dirk, H. E. Katz, M. L. Schilling, L. A. King, Chem. Mat. 1990, 2, 700. ${ }^{[2 b]}$ R. D. Miller, V. Y. Lee, C. R. Moylan, Chem. Mat. 1994, 6, 1023. ${ }^{[2 c]}$ V. P. Rao, A. K.-Y. Jen, K. Y. Wong, K. J. Drost, Tetrahedron Lett. 1993, 34, 1747.

${ }^{[3][3 a]}$ P. R. Varanasi, A. K.-Y. Jen, J. Chandrasekhar, I. N. N. Namboothiri, A. Rathna, J. Am. Chem. Soc. 1996, 118, 12443. ${ }^{[3 b]}$ I. D. L. Albert, T. J. Marks, M. A. Ratner, J. Am. Chem. Soc. 1997, 119, 6575. ${ }^{[3 c]}$ E. M. Breitung, C.-F. Shu, R. J. McMahon, J. Am. Chem. Soc. 2000, 122, 1154. ${ }^{[3 \mathrm{~d}]}$ P. Hrobarik, P. Zahradnik, W. M. F. Fabian, Phys. Chem. Chem. Phys. 2004, 6, 495.

${ }^{[4]}{ }^{[4 a]}$ T. L. Gilchrist In: Heterocyclic Chemistry, Wiley: New York, 1985. ${ }^{[4 b]}$ C.-F. Shu, Y.-K. Wang, J. Mat. Chem. 1998, 8, 833.

${ }^{[5] ~[5 a]}$ M. M. M. Raposo, G. Kirsch, Heterocycles 2001, 55, 1487. ${ }^{[5 \mathrm{~b}]}$ M. M. M. Raposo, G. Kirsch, Tetrahedron 2003, 59, 4891. ${ }^{[5 \mathrm{c}]}$ M. M. M. Raposo, A. M. C. Fonseca, G. Kirsch, Tetrahedron 2004, 60, 4071. ${ }^{[5 \mathrm{~d}]}$ G. Zotti, S. Zecchin, B. Vercelli, A. Berlin, M. C. Pasini, S. Destri, W. Porzio, M. M. M. Raposo, Chem. Mat. 2005, 17, 6492. ${ }^{[5 e]}$ S. P. G. Costa, J. A. 
Ferreira, G. Kirsch, A. M. F. Oliveira-Campos, J. Chem. Res. 1997, (S), 314; (M), 2001. ${ }^{[5 f]}$ X. H. Luan, N. M. F. S. A. Cerqueira, A. M. A. G. Oliveira, M. M. M. Raposo, L. M. Rodrigues, P. Coelho, A. M. F. Oliveira-Campos, Adv. Colour Sci. Tech. 2002, 5, 18. ${ }^{[5 \mathrm{~g}]}$ P. C. R. SoaresSantos, M. M. M. Raposo, S. P. G. Costa, A. M. F. Oliveira-Campos, Adv. Colour Sci. Tech. 2002, 5, 94. ${ }^{[5 \mathrm{~h}]}$ R. M. F. Batista, S. P. G. Costa, M. M. M. Raposo, Tetrahedron Lett. 2004, 45, 2825. ${ }^{[5 \mathrm{i}]}$ M. M. M. Raposo, A. M. B. A. Sampaio, G. Kirsch, Synthesis 2005, 2, 199. ${ }^{[5 \mathrm{j}]}$ M. M. M. Raposo, A. M. R. C. Sousa, A. M. C. Fonseca, G. Kirsch, Tetrahedron 2005, 61, 8249. ${ }^{[51]}$ M. M. M. Raposo, A. M. R. C. Sousa, G. Kirsch, F. Ferreira, M. Belsey, E. de Matos Gomes; A. M. C. Fonseca, Tetrahedron 2005, 61, 11991. ${ }^{[5 \mathrm{~m}]}$ M. M. M. Raposo, A. M. B. A. Sampaio, G. Kirsch, J. Heterocyclic Chem. 2005, 42, 7, 1245. ${ }^{[5 n]}$ F. Costa, C. J. R. Silva; M. M. M. Raposo, A. M. Fonseca, I. C. Neves, A. P. Carvalho, J. Pires, Microporous Mesoporous Mater. 2004, 72, 111. ${ }^{[50]}$ A. M. C. Fonseca, M. M. M. Raposo, A. M. R. C. Sousa, G. Kirsch, M. Belsley, Eur. J. Inorg. Chem. 2005, 21, 4361.

[6] [6a] A. Molinos-Gómez, X. Vidal, M. Maymó, D. Velasco, J. Martorell, F. LópezCalahorra, Tetrahedron 2005, 61, 9075. ${ }^{[6 b]}$ P. Hrobárik, I. Sigmundová, P. Zahradník, Synthesis 2005, 600. ${ }^{[6 \mathrm{c}]}$ S. K. Park, J. Y. Do, J. J. Ju, S. Park, M.-s. Kim, M.-H Lee, Mat. Lett. 2005, 59, 2872. ${ }^{[6 \mathrm{~d}]}$ P. G. Lacroix, I. I. Padilla-Martínez, H. S. López, K. Nakatani, New. J. Chem. 2004, 28, 542. ${ }^{[6]}$ F. Lopez-Calahorra, M. Martínez-Rubio, D. Velasco, E. Brillas, L. Julià, Tetrahedron 2004, 60, 285. ${ }^{[6 f]}$ X. J. Liu, W. N. Leng, J.-K. Feng, A. M. Reng, X. Zou, Chinese J. Chem. 2003, 21, 9. ${ }^{[6 \mathrm{~g}]}$ W. N. Leng, Y. N. Zou, Q. H. Xu, J. Z. Liu, Polymer 2001, 42, 9253. ${ }^{[6 \mathrm{~h}]}$ W. N. Leng, Y. Zou, Q. H. Xu, J. Z. Liu, Macromolecules 2001, 34, 4774. ${ }^{[6 \mathrm{i}]}$ H.Q. Xie, Z.-H. Liu, X.-D. Huang, J.-S. Guo, Eur. Polym. J. 2001, 37, 497.

${ }^{[7]}$ A. Ohta, Y. Akita, T. Ohkuwa, M. Chiba, R. Fukunaga, A. Miyafuji, T. Nakata, N. Tani, Y. Aoyagi, Heterocycles 1990, 31(11), 1951.

${ }^{[8]}$ R. Frimm, L. Fišera, J. Kováč, Collect. Czech. Chem. Commun. 1973, 38, 1809.

${ }^{[9]}$ W. Sato, T. Nakai, S. Akiyama, T. Yionyama, Chem. Abstr. 2004, 140, P 171934w.

${ }^{[10]}$ G. Mignani, F. Leising, R. Meyrueix, H. Samson, Tetrahedron Lett. 1990, 31(33), 4743.

${ }^{[11]}$ N. V. Stulin, A. E. Lipkin, D. A. Kulilova, E. A. Rudzit, Pharm. Chem. J. (Eng. Transl.) 1975, 9, 702 .

${ }^{[12]}$ J. C. Bussolari, D. C. Rehborn, Org. Lett. 1999, 1(7), 965.

${ }^{[13]}$ T. G. Deligeorgiev, Dyes Pigments 1990, 12, 243. 
${ }^{[14]}{ }^{[14 a]}$ I. Timtcheva, T. G. Deligeorgiev, Dyes Pigments 1993, 21, 293. ${ }^{[14 b]}$ I. Petrov, T. G. Deligeorgiev, I. Timtcheva, Dyes Pigments 1997, 35(2), 171.

${ }^{[15]}$ F. Effenberger, F. Wuerthner, F. Steybe, J. Org. Chem. 1995, 60, 2082.

${ }^{[16]}$ M. J. Kamlet, J.-L. Abboud, M. H. Abraham, R. W. Taft, J. Org. Chem. 1983, 48, 2877.

${ }^{[17]}$ K. Clays, A. Persoons, Rev. Sci. Instrum. 1992, 63, 3285.

${ }^{[18]}$ K. Clays, A. Persoons, Phys. Rev. Lett. 1991, 66, 2980.

${ }^{[19]}{ }^{[19 a]}$ J. L. Oudar, J. Chem. Phys. 1977, 67, 446. ${ }^{[19 b]}$ J. L. Oudar, D. S. Chemla, J. Chem. Phys. 1977, 66, 2664. ${ }^{[19 c]}$ J. Zyss, J. L. Oudar, Phys. Rev. A 1982, 26, 2016.

${ }^{[20]}{ }^{[20 a]}$ C. C. Teng, A. F. Garito, Phys. Rev. B 1983, 28, 6766. ${ }^{[20 b]}$ M. Stahelin, D. M. Burland, J. E. Rice, Chem. Phys. Lett., 1992, 191, 245. 